\title{
Phytoplankton motility and the competition for nutrients in the thermocline
}

\author{
Oliver N. Ross ${ }^{1, *}$, Jonathan Sharples ${ }^{2}$ \\ ${ }^{1}$ Department of Biological Sciences, University of Essex, Wivenhoe Park, Colchester CO4 3SQ, UK \\ ${ }^{2}$ Proudman Oceanographic Laboratory, Joseph Proudman Building, 6 Brownlow Street, University of Liverpool, \\ Liverpool L3 5DA, UK
}

\begin{abstract}
Diatoms and dinoflagellates are 2 important groups of phytoplankton that co-exist in the competition for light and nutrients. Following the diatom-dominated spring bloom, the shelf sea subsurface chlorophyll maximum (SCM) is often dominated by motile species of phytoplankton, in particular dinoflagellates and sometimes coccolithophores. Turbulence in shelf seas, driven by surface winds and by tidal currents, is likely to easily counteract the typically weak swimming capabilities of phytoplankton. The thermocline marks a low turbulence region, separating the nutrient-depleted surface (wind-mixed) layer and the nutrient-replete bottom (tidally-mixed) layer, and so would seem to be an ideal environment for employing a strategy of vertical migration. However, the positioning within the thermocline is crucial, as turbulence in the adjoining boundary layers removes cells that stray too close to the edges of the thermocline and mixes them into resource-limited layers of the water column. We combined a Lagrangian random walk model, a $k-\varepsilon$ turbulence scheme and a simple photosynthesis model to track individual phytoplankton cells in a tidally-mixed, stratified water column (e.g. a summer, temperate shelf sea). By allowing motile and non-motile species to compete, we found that an ability to use motility to balance resource requirements can offset modest physiological disadvantages compared to the non-motile phytoplankton, leading to either co-existence or even dominance of the motile species. However, more severe physiological disadvantages (e.g. combinations of growth rate, nutrient uptake capabilities, and/or respiration) cannot be compensated for by motility alone, and further adaptations (such as mixotrophy) would be required. We also show that the SCM can be a place for significant new production (values of $1 \mathrm{~g} \mathrm{C} \mathrm{m}^{-2} \mathrm{~d}^{-1}$ and $f$-ratios of over 0.5 are possible), which stresses its potential importance as a source of food to the pelagic throughout summer.
\end{abstract}

KEY WORDS: Phytoplankton species competition · Motility · Tidal mixing · Shelf sea thermocline · Carbon export $\cdot$ Nitrogen flux $\cdot f$-ratio $\cdot$ Turbulence modelling $\cdot$ Lagrangian modelling

\section{INTRODUCTION}

Diatoms, dinoflagellates, and coccolithophores are important groups of phytoplankton that compete for light and nutrients in the sea. They are responsible for most of the organic fuel supplied to the higher marine trophic levels, and about half of the global net primary production (Field et al. 1998). In the water column, these primary producers are generally not homogeneously distributed with depth, but often form a (macroscopic) layer of maximum concentration. In sub- tropical regions, this maximum occurs between 60 and 120 m (e.g. Anderson 1969, Bienfang 1983, Huisman 2006) and is often referred to as the deep chlorophyll maximum or subsurface chlorophyll maximum (SCM). In temperate regions and shelf seas, the SCM occurs only seasonally and at more shallow depths (e.g. Cullen 1981b, Sharples 2001). SCM formation was also successfully reproduced in several Eulerian (Tett 1981, Sharples \& Tett 1994, Sharples 1999) and Lagrangian model studies (Woods \& Barkmann 1994, Broekhuizen 1999). The underlying mechanisms that lead to the 
formation of SCMs are well understood: 2 opposing resource gradients combined with a vertically heterogeneous turbulent mixing render only a certain region of the water column amenable for survival (cf. Fig. 1). However, our present understanding is rather limited if we attempt to explain the underlying mechanisms which determine the species composition within a particular SCM, the relative dominance of a particular phytoplankton group, or the transition from one dominant group to another.

Diatoms are often found to dominate in more turbulent environments, such as the developing stratification at the spring bloom (e.g. Lochte et al. 1993, Townsend \& Thomas 2002) and the transient blooms associated with upwelling events (e.g. Tilstone et al. 2000). The vertical mixing in these environments is thought to be a key aspect of diatom survival (Tooby et al. 1977, Margalef 1978, Huisman \& Sommeijer 2002), with the generally negatively-buoyant, non-motile cells being dependent on turbulence to keep re-suspending them into the photic zone (Ross 2006). On the other hand, dinoflagellates and coccolithophores are found in regions with established stratification, either co-existing with or sometimes dominating diatoms (e.g. Holligan \& Harbour 1977, Pingree et al. 1982, Sharples et al. 2001). In contrast to the diatoms, both dinoflagellates and coccolithophores are motile, capable of directed swimming at typical sustained speeds of 0.1 to $0.5 \mathrm{~mm} \mathrm{~s}^{-1}$ (Eppley et al. 1967, Kamykowski \& McCollum 1986, Levandowski \& Kaneta 1987) although some velocities above $1.4 \mathrm{~mm} \mathrm{~s}^{-1}$ have been reported (Lombardi \& Capon 1971, Horstmann 1980). This directed motility has been suggested as a mechanism to allow a cell to control its vertical position depending on resource requirements. Dinoflagellates have been observed to swim vertically to gather sufficient light (more abundant towards the surface) and nutrients (more abundant in deeper water) both in laboratory experiments (Cullen \& Horrigan 1981) and in the real environment (Eppley et al. 1968). Vertical migration is also thought to play a role in the concentrations of toxins in dinoflagellates (Flynn 2002); because $90 \%$ of toxic phytoplankton species are motile dinoflagellates or flagellates (Smayda 1997), there is an important practical need to understand the role of motility in the context of our understanding of the ecology of harmful algal blooms.

In addition to differences in swimming capability, dinoflagellates (in particular) are believed to have significant physiological disadvantages compared to diatoms. For instance, dinoflagellates are thought to have lower photosynthetic rates (e.g. Fur- nas 1990, Tang 1995), higher metabolic costs and nutrient affinity (or half-saturation) coefficients (Smayda 1997). These disadvantages suggest that dinoflagellates need some other adaptation(s) to allow the observed co-existence with, or dominance over, diatoms. Vertical migration, mixotrophy, chemicallyregulated inter-specific competition, and anti-predation defence have been suggested as possible adaptations (see Smayda 1997).

This paper focuses on the role that vertical migration of motile cells may play in the competition between phytoplankton species within the SCM in the seasonal thermocline of temperate shelf seas. In many seasonally-stratifying shelf environments, the thermocline is a relatively quiescent turbulent region, separating wind-mixed and, particularly, tidallymixed layers. The magnitudes of the turbulent velocities reached in these mixed layers can easily exceed the typical dinoflagellate swimming velocities by 1 or 2 orders of magnitude (cf. Fig. 3.8 in Yamazaki et al. 2002). The pursuit of a vertical migration strategy or the general use of motility in such an environment is therefore not clear a priori. The only region where vertical migration seems feasible is the thermocline, where density stratification dampens vertical turbulent motions, producing a calm sanctuary within an otherwise highly turbulent environment. The thermocline is also the site of a sharp nutrient gradient (e.g. Sharples et al. 2001) where a short swimming distance can potentially yield large changes in ambient nutrient concentrations. Episodic tidal mixing events have been observed to intrude into the base of the thermocline, however, and erode part of the SCM into the turbulent bottom mixed layer (BML) where the cells become light limited (Sharples et al. 2001)

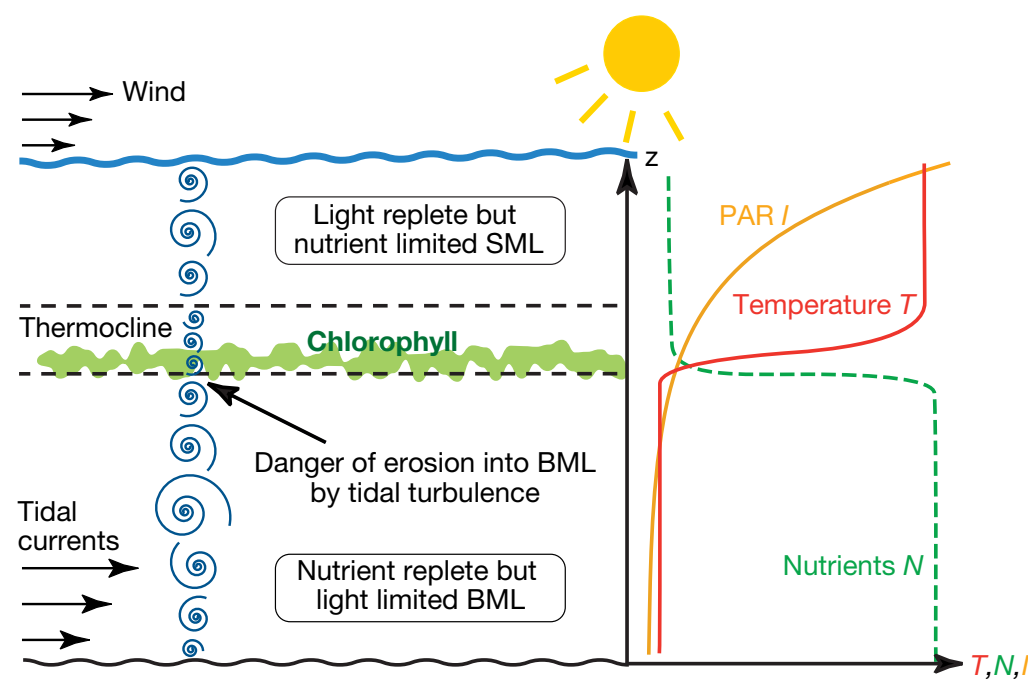

Fig. 1. Schematic of a stratified shelf sea. The various spiral sizes give an indication of the varying turbulent intensity within the water column.

(Drawn after observations by Sharples et al. 2001) 


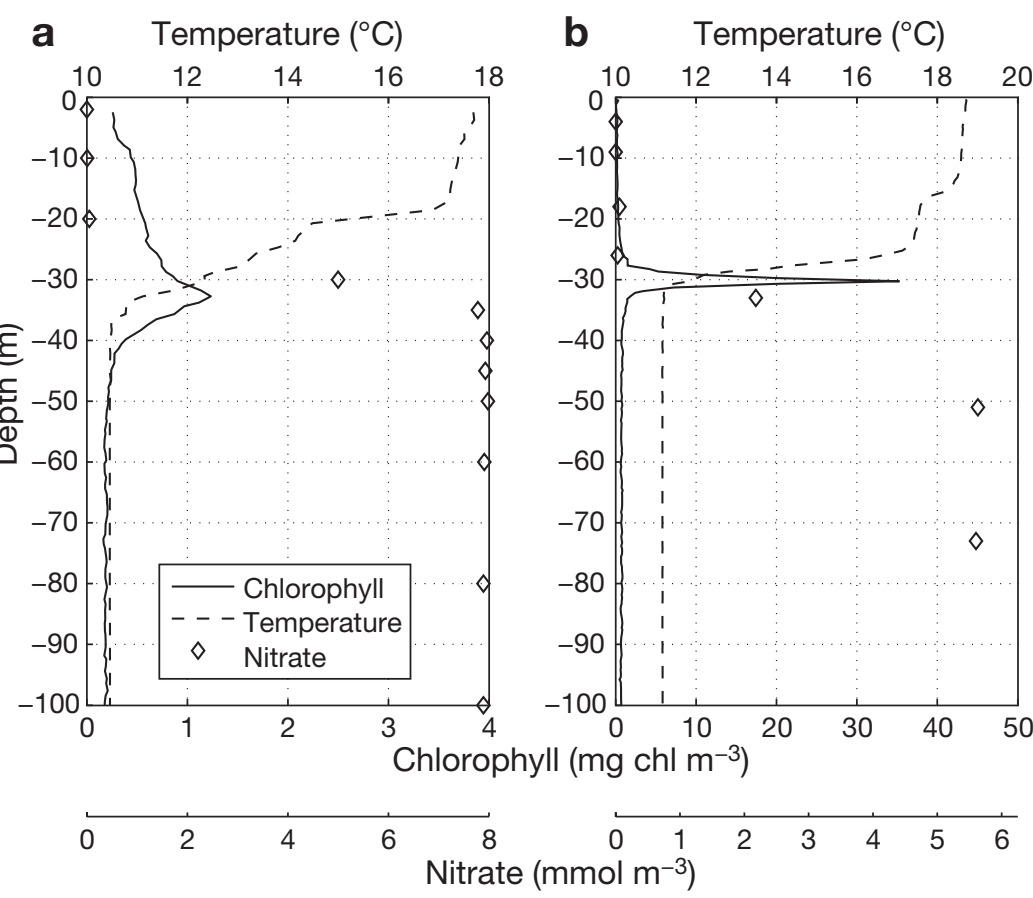

Fig. 2. Vertical profiles of temperature, chlorophyll and nitrate concentration for 2 different locations in a summer-stratified shelf sea. Profile (a) is from a representative station in the Celtic Sea, with a sub-surface population consisting of diatoms, dinoflagellates, flagellates, and coccolithophores. Profile (b) was taken in the western English Channel, and had a highly concentrated, mono-specific population consisting of the motile coccolithophore Calyptrosphaera oblonga

synthesis model which also incorporates photo-acclimation and -inhibition (Denman \& Marra 1986). Mathematically, the Lagrangian approach is superior to the (computationally faster) ensemble-average (Eulerian) approach of modelling marine ecosystems, as it does not entail averaging of the non-linear equations prior to their integration (e.g. Woods \& Onken 1982). Lagrangian models also have the advantage of allowing each individual cell's physiological state, such as light acclimation or nutrient status, to be tracked (e.g. Lizon et al. 1998, Broekhuizen 1999). In the context of the present work, this allowed an investigation of a species-dependent, physiologically-controlled migration strategy not amenable to the ensemble approach.

Initially we demonstrated that a single non-motile (diatom) species rapidly develops a surface spring bloom, followed by a subsurface maximum fuelled by the flux of nitrogen into the base of the thermocline from below. We then added a second species: a dinoflagellate with significant physiological disadvantages compared to the diatom. Initially, the dinoflagellate was set to be non-motile to demonstrate that the physiological impairment indeed results in it

(Fig. 1); thus, swimming deeper into the nitracline does involve some risk to a phytoplankton cell. Ross \& Sharples (2007) have shown how a small swimming capability is sufficient to greatly increase the chances for re-accessing the thermocline from the BML, which may be a reason why motile cells are able to co-exist with diatoms in many sub-surface chlorophyll maxima (Fig. 2a) and sometimes form very high, mono-specific concentrations (Fig. 2b).

We thus investigated the role of phytoplankton motility on spatial scales on the order of 1 to $10 \mathrm{~m}$. The main issue we aimed to address was: Does the capability of directed vertical swimming allow motile phytoplankton species (potentially physiologically impaired, as suggested above) to compete successfully with nonmotile species in the struggle for nutrients within the shelf sea seasonal thermocline? Also, we attempted to quantify the fluxes of carbon and nitrogen across the thermocline.

We utilised a recently developed Lagrangian random walk model (Ross \& Sharples 2004) in combination with a model of a tidally-driven temperate shelf sea water column (Sharples et al. 2006), incorporating the spatial and temporal heterogeneity of marine turbulence and a simple nutrient-quota based photo- being rapidly out-competed by the diatoms. The dinoflagellate was then allowed to migrate vertically in response to resource requirements, and we explored the possibility of motility counteracting the physiological disadvantage to allow co-existence of motile and nonmotile species. In the discussion we examine the dependence of the results on the chosen parameter values and discuss implications for the shelf-sea ecosystem.

\section{METHODS}

The model consists of 3 components: (1) a $k$ - $\varepsilon$ turbulence model to deliver vertical profiles of turbulent eddy diffusivity based on the amount of tidal forcing and the ambient water column stability, (2) a Lagrangian particle tracking model to describe the vertical displacement of cells in response to turbulence and cell motility, and (3) a biological component which calculates the primary production based on the available light and nutrients, which in turn feeds into the swimming behaviour of the motile species. Each of these components is described in more detail in the following sections and Table 1 provides a summary of the main model parameters. 
The physical environment. The question addressed requires a relatively sophisticated turbulence model capable of capturing the temporal and spatial variability of the tidally driven mixing in the bottom layer. Simpson et al. (1996) showed that for a stratified shelf sea, a second order turbulence closure model delivers a very good representation of the turbulent dissipation in the BML. The present study used a 2-equation model of the $k-\varepsilon$ variety (Canuto et al. 2001, Sharples et al. 2006), which has been shown to be equivalent (Burchard \& Bolding 2001) to the 2-equation MellorYamada (MY) model used by Simpson et al. (1996) (Mellor \& Yamada 1982). A parametrisation for internal wave mixing at the thermocline was included following Large et al. (1994) (see Sharples et al. 2006 for details).

Table 1. Main model parameters, common symbols and abbreviations used throughout the text. Sources are 1: Broekhuizen (1999), 2: Sharples et al. (2001), 3: Sharples (1999), 4: Brand \& Guillard (1981), 5: Dortch \& Maske (1982), 6: Sarthou et al. (2005), a: assumed, v: variable

\begin{tabular}{|c|c|c|c|}
\hline Symbol & Description & Value/Unit & \\
\hline $\mathrm{C}_{\text {starve }}$ & Cellular carbon starvation threshold & $1 \times 10^{-6} \mathrm{mg} \mathrm{C}$ & 1 \\
\hline $\mathrm{C}_{\text {fission }}$ & Cellular carbon level for cell division & $3 \times 10^{-6} \mathrm{mg} \mathrm{C}$ & 1 \\
\hline$f_{1}$ & If $Q<f_{1} Q_{\max }$ cell swims down & 0.675 & $\mathrm{a}$ \\
\hline$f_{2}$ & If $Q>f_{2} Q_{\max }$ cell swims up & 0.75 & a \\
\hline$G$ & Grazing rate & $0.1 \mathrm{~d}^{-1}$ & 3 \\
\hline$H$ & Total water depth & $80 \mathrm{~m}$ & - \\
\hline$I_{\mathrm{b}}$ & Lower inhibition threshold & 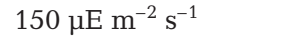 & a \\
\hline$I_{\mathrm{c}}$ & Critical light intensity for phototaxis & $0.1 \mu \mathrm{E} \mathrm{m} \mathrm{m}^{-2} \mathrm{~s}^{-1}$ & $\mathrm{a}$ \\
\hline$I_{1} / I_{\mathrm{d}}$ & Light/dark saturation onset irradiance & $50 \mu \mathrm{E} \mathrm{m} \mathrm{m}^{-2} \mathrm{~s}^{-1}$ & 4 \\
\hline$I_{0}$ & Midday surface PAR & $1030 \mu \mathrm{E} \mathrm{m} \mathrm{m}^{-2} \mathrm{~s}^{-1}$ & 2 \\
\hline$k_{\mathrm{bg}}$ & Light absorption (background opacity) & $0.09 \mathrm{~m}^{-1}$ & 2 \\
\hline$k_{\mathrm{C}}$ & C-specific light absorption (self-shading) & $0.0004 \mathrm{~m}^{2}(\mathrm{mg} \mathrm{C})^{-1}$ & 1 \\
\hline$K$ & Vertical eddy diffusivity & $\mathrm{m}^{2} \mathrm{~s}^{-1}$ & - \\
\hline$L r$ & Loss rate if $\mathrm{C}<\mathrm{C}_{\text {starve }}$ & $0.1 \mathrm{~d}^{-1}$ & 3 \\
\hline$N_{i}$ & Dissolved nitrogen conc. in $i$ th depth element & $\mathrm{mg} \mathrm{N} \mathrm{m}^{-3}$ & - \\
\hline$N_{\text {bed }}$ & Nitrogen conc. in bottom depth element & $70.0 \mathrm{mg} \mathrm{N} \mathrm{m}^{-3}$ & 2 \\
\hline$\hat{N}_{i}$ & Cellular nitrogen conc. in $i$ th depth element & $\mathrm{mg} \mathrm{N} \mathrm{m}^{-3}$ & - \\
\hline$\left(P_{\mathrm{m}}^{\mathrm{d}}\right)_{\mathrm{dino}}$ & Dinofl. max. dark acclimatised growth rate & $2.174 \times 10^{-5} \mathrm{~s}^{-1}$ & 4 \\
\hline$\left(P_{\mathrm{m}}^{1}\right)_{\text {dino }}$ & Dinofl. max. light acclimatised growth rate & $1.085 \times 10^{-5} \mathrm{~s}^{-1}$ & 4 \\
\hline$\left(P_{\mathrm{m}}^{\mathrm{d}}\right)_{\text {diat }}$ & Diatom max. dark acclimatised growth rate & $3.612 \times 10^{-5} \mathrm{~s}^{-1}$ & $\mathrm{~V}$ \\
\hline$\left(P_{\mathrm{m}}^{1}\right)_{\text {diat }}$ & Diatom max. light acclimatised growth rate & $1.812 \times 10^{-5} \mathrm{~s}^{-1}$ & $\mathrm{~V}$ \\
\hline$Q_{\min }$ & Subsistence nitrogen-to-carbon quota & $0.056 \mathrm{mg} \mathrm{N}(\mathrm{mg} \mathrm{C})^{-1}$ & 1 \\
\hline$Q_{\max }$ & Maximum nitrogen-to-carbon storage quota & $0.28 \mathrm{mg} \mathrm{N}\left(\mathrm{mg} \mathrm{C}^{-1}\right.$ & 1 \\
\hline$r_{\text {diat/dino }}$ & Diatom/dinoflagellate metabolic cost & $0.1 / 0.1 \mathrm{~d}^{-1}$ & 3 \\
\hline$\Delta t$ & Model time step & $6 \mathrm{~s}$ & - \\
\hline$T_{\mathrm{D}}$ & Light period & $16 \mathrm{~h}$ & 2 \\
\hline$U_{\max }$ & Maximum C-specific nitrogen uptake rate & $0.95 \mathrm{mg} \mathrm{N}(\mathrm{mg} \mathrm{C} \mathrm{d})^{-1}$ & 5 \\
\hline$W_{\text {diat }}$ & Diatom single cell sinking velocity (if $\mathrm{N}$ limited) & $1.2 \times 10^{-5} \mathrm{~m} \mathrm{~s}^{-1}$ & 6 \\
\hline$W_{\text {dino }}$ & Plankton swimming velocity & $10^{-4} \mathrm{~m} \mathrm{~s}^{-1}$ & 2 \\
\hline$z$ & Vertical position as height above bed $(z>0)$ & $\mathrm{m}$ & - \\
\hline$\beta$ & Fraction of grazed nitrogen that is recycled & 0.5 & 3 \\
\hline$\kappa_{\mathrm{N}}$ & Nutrient affinity (half saturation constant) & $3.0 \mathrm{mg} \mathrm{N} \mathrm{m}^{-3}$ & 1 \\
\hline \multicolumn{4}{|c|}{ Abbreviations } \\
\hline \multicolumn{4}{|c|}{ BML/SML Bottom/Surface mixed layer } \\
\hline \multicolumn{4}{|c|}{ DIN $\quad$ Dissolved inorganic nitrogen } \\
\hline $\mathrm{SCM}$ & Subsurface chlorophyll maximum & & \\
\hline
\end{tabular}

The model was set up with a total water depth of $80 \mathrm{~m}$ and uses a fixed vertical temperature profile, in which a homogeneous surface layer (thickness $20 \mathrm{~m}$ ) was separated from a $50 \mathrm{~m}$ thick BML by an almost linear thermocline between 50 and $60 \mathrm{~m}$ above the bed (Fig. 3a). The constant temperature difference of $3.5^{\circ} \mathrm{C}$ was maintained across the thermocline simply by disabling the advection-diffusion equation for $T$ (Eulerian). This did not affect the exchange of nutrients or particles (Lagrangian), which were handled differently in the model (see Ross \& Sharples 2007 for details). This simplification enabled us to measure fluxes out of and into the thermocline more easily by simply specifying a fixed thermocline depth. We also found that experiments in which the thermocline was freely moving did not seem to alter the results much (not shown) because the M2 tidal variability was too quick for the thermocline to respond to, producing a quasi-stable mean level. The spring-neap cycle is a different matter, as the timescale of mixing variability is slow enough for the thermocline to respond, but we do not address that here. The model was forced only by a barotropic pressure gradient oscillating at the semi-diurnal M2 tidal frequency. The resulting time series of tidal currents (Fig. 3b) is similar to the one observed close to a spring tide in a summer stratified shelf sea with current amplitudes reaching $0.75 \mathrm{~m} \mathrm{~s}^{-1}$ for the maximum ebb/flood flows (Sharples et al. 2001).

These high current amplitudes were chosen expressly in order to test the use of motility in a highly turbulent environment. A quadratic friction boundary condition at the seabed generates the vertical current shear, which in turn yields the desired profiles of turbulent intensity (Fig. 3c). Turbulence is thus parameterised through the eddy diffusivity $K$. The 2 diffusivity maxima in the BML correspond to the ebb and flood flows, which produce turbulent diffusivities in excess of $10^{-2} \mathrm{~m}^{2} \mathrm{~s}^{-1}$. As the thermocline is approached, turbulence decreases rapidly and in the stratified region $K$ drops below $10^{-5} \mathrm{~m}^{2} \mathrm{~s}^{-1}$.

The noon irradiance of photosynthetically active radiation (PAR) was 1030 $\mu \mathrm{E} \mathrm{m}^{-2} \mathrm{~s}^{-1}$ on each model day, with a day consisting of a semi-sinusoidal variation of surface irradiance over $16 \mathrm{~h}$ of daylight and an $8 \mathrm{~h}$ period of dark- 
ness. The irradiance was distributed exponentially through the water, with the light received by a Lagrangian particle at height $z$ given by:

$$
I(z)=I_{0} \exp [-k(H-z)]
$$

where $I_{0}$ is the PAR at the sea surface $(z=H)_{;} H$ is the total depth of the water column; and $k=k_{\mathrm{bg}}+k_{\mathrm{s}}(z)$ is the light attenuation coefficient consisting of a component due to the background water opacity, $k_{\mathrm{bg}}$, and a component due to self shading, $k_{\mathrm{s}}(z)$. The latter depends on the number of phytoplankton cells (literally the amount of carbon) between the surface and height $z: k_{\mathrm{s}}(z)=k_{\mathrm{C}} \overline{\mathrm{C}}$, where $k_{\mathrm{C}}=0.0004 \mathrm{~m}^{2}\left(\mathrm{mg} \mathrm{C}^{-1}\right.$ is the carbon specific absorption coefficient (cf. Broekhuizen 1999) and $\bar{C}$ is the average carbon concentration in the water column between the particle position and the surface.

The random walk method. The profiles of the eddy diffusivity, $K$, obtained from the $k-\varepsilon$ model (see previous section) were used to provide the random, turbulent stirring of Lagrangian particles. The 1-dimensional (vertical) particle-tracking model is based on Ross \& Sharples (2004). At the beginning of each experiment, the Lagrangian particles were distributed homogeneously throughout the water column. During a time step a particle was moved from its previous position, $z_{n}$, to its new position, $z_{n+1}$, using (Hunter et al. 1993, Visser 1997):

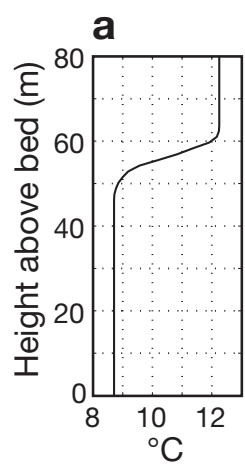

\section{b}

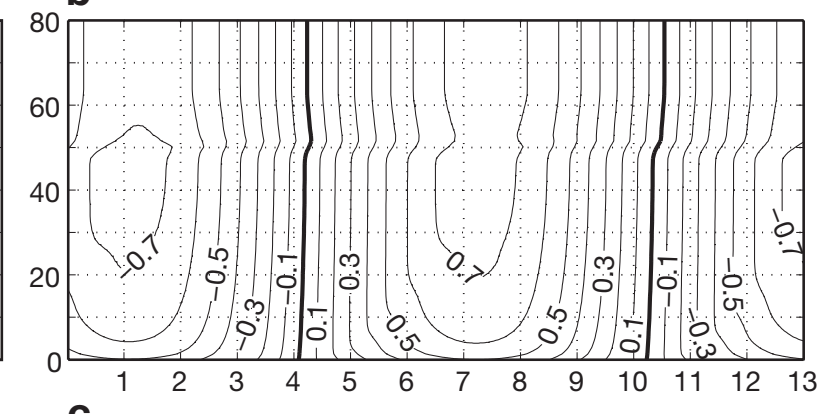

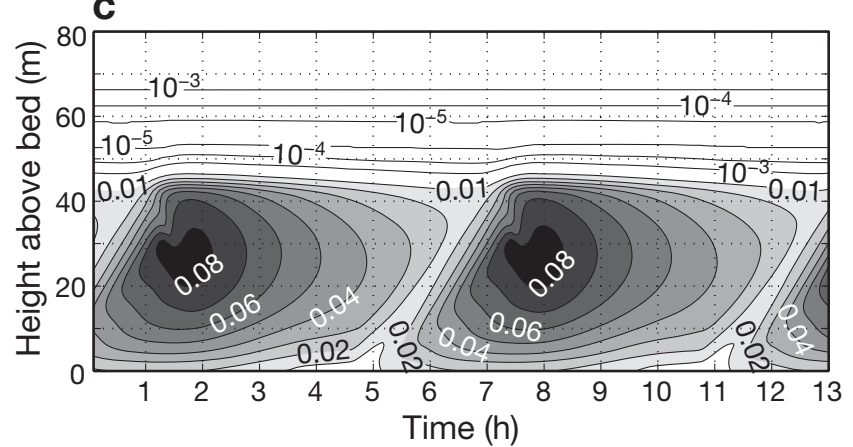

Fig. 3. Physical conditions used by the Lagrangian model. (a) Vertical temperature profile and (b) tidal cycle of currents (values in $\mathrm{m} \mathrm{s}^{-1}$ ) used to calculate vertical eddy diffusivities. (c) Resulting depth and time variations of vertical eddy diffusivities $\left(K\right.$ in $\mathrm{m}^{2} \mathrm{~s}^{-1}$ ). The $K$-profiles are calculated at $1 \mathrm{~m}$ depth intervals using the $k$ - $\varepsilon$ turbulence model and smoothed with a cubic spline for use in the random walk of Eq. (2) (see text)

$$
\begin{aligned}
z_{n+1}=z_{n}+\underbrace{W_{\mathrm{p}} \Delta t}_{\begin{array}{c}
\text { swimming/ } \\
\text { sinking }
\end{array}}+\underbrace{K^{\prime}\left(z_{n}\right) \Delta t}_{\text {deterministic term }} \\
+R \underbrace{}_{\text {random term }} \underbrace{\left[\frac{2 K\left(z_{n}+\frac{1}{2} K^{\prime}\left(z_{n}\right) \Delta t\right) \Delta t}{r}\right]^{1 / 2}}
\end{aligned}
$$

$z_{n}$ in Eq. (2) denotes the vertical position of the particle after $n$ iterations, $w_{\mathrm{p}}$ is the vertical sinking/swimming velocity, and $K^{\prime}=\mathrm{d} K / \mathrm{d} z$. $\Delta t$ is the time step for the iteration and $R$ is a random process of zero mean and variance $r$ (e.g. $r=\frac{1}{3}$ for $R \in[-1,1]$ ). As outlined by Visser (1997), the use of Eq. (2) requires that the profiles of $K$ and $K^{\prime}$ are continuous and differentiable, so each $K$ profile from the $k-\varepsilon$ model was fitted with a cubic spline (see Ross \& Sharples 2004 for details). The time step in Eq. (2) was chosen according to Eq. (8) in Ross \& Sharples (2004) to yield an error of less than 1\% at all times. By performing an experiment with 10000 nonmotile, non-growing and neutrally buoyant particles (not shown) we also ensured that this $1 \%$ error neither built up over the length of an 80 d experiment nor did it lead to artificial particle accumulations.

The top and bottom boundaries are reflecting according to:

$$
z_{n+1} \rightarrow \begin{cases}-z_{n+1} & , \text { if } z_{n+1}<0 \\ 2 H-z_{n+1}, & \text { if } z_{n+1}>H\end{cases}
$$

where $H$ is the total water column depth. In the cubic splines we forced $K^{\prime}=0$ at the top and bottom boundaries at all times to avoid problems with the reflecting boundary condition (see Ross \& Sharples 2004 for details).

The biological model. Each phytoplankton species in the model was represented by 10000 Lagrangian particles initially distributed uniformly in the water column. Each particle initially carried $10^{5}$ phytoplankton cells and each cell had a carbon weight of $2 \times 10^{-6} \mathrm{mg} \mathrm{C}$ and a $\mathrm{N}$ : C ratio of $Q=0.8 Q_{\max }$ (cf. Table 1 ). Within each Lagrangian particle, all phytoplankton cells had the same physiological characteristics (Lagrangian Ensemble method); the growth of the phytoplankton cells was determined by the light available for photosynthesis at the position of the particle (taking into account self-shading), the recent light history of the particle, and the internal nutrient status of the cells.

The light-nutrient-production model: Light-dependent growth was modelled following Denman \& Marra (1986) (see also 
Nagai et al. 2003), taking into account photo-acclimation based on the recent light experienced by the Lagrangian particle. The production rate of the cells within a Lagrangian particle lies between high-light acclimatised $P^{\mathrm{l}}$ and low-light (dark) acclimatised $P^{\mathrm{d}}$ rates:

$P^{\mathrm{l}}=P_{\mathrm{m}}^{\mathrm{l}}\left[1-\exp \left(-I / I_{1}\right)\right]$ and $P^{\mathrm{d}}=P_{\mathrm{m}}^{\mathrm{d}}\left[1-\exp \left(-I / I_{\mathrm{d}}\right)\right]$

with $P_{\mathrm{m}}^{\mathrm{d}} / P_{\mathrm{m}}^{\mathrm{l}}\left[\mathrm{s}^{-1}\right]$ the maximum production rates for cells fully acclimatised to the dark or high light respectively. $I_{\mathrm{d}} / I_{1}$ is the saturation onset for the dark- and light-acclimatised production curves, and $I$ is the light intensity at the particle position from Eq. (1). At each particle position a local acclimation parameter, $0 \leq X(I) \leq 1$, is defined as the acclimation status a phytoplankton cell would achieve if it were held at that position (i.e. at that irradiance) for a long time:

$$
X(I)=1-\exp \left[-\left(\frac{I-I_{\mathrm{b}}}{I_{\mathrm{b}}}\right)^{2}\right]
$$

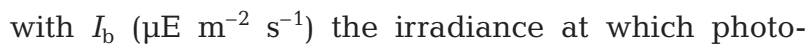
acclimation begins. As the cells move through the water column, the new cell acclimation status, $Y_{n+1}$, relates to the previous cell acclimation status, $Y_{n}$, by:

$$
Y_{n+1}=Y_{n}+\frac{1}{\tau_{\mathrm{a}}}\left(X(I)-Y_{n}\right) \Delta t
$$

where $\tau_{\mathrm{a}}=1 \mathrm{~h}$ is the acclimation time scale. The instantaneous production rate $\left(P_{\mathrm{I}}\right)$ based on the light availability is then calculated from:

$$
P_{\mathrm{I}}=P^{\mathrm{d}}+Y\left(P^{\mathrm{l}}-P^{\mathrm{d}}\right)
$$

For the motile species in the experiment, the value for $P_{\mathrm{m}}^{\mathrm{d}}$ was chosen to allow growth rates of one doubling per day at an irradiance of approximately $30 \mu \mathrm{E}$ $\mathrm{m}^{-2} \mathrm{~s}^{-1}$ (Brand \& Guillard 1981). The value of $P_{\mathrm{m}}^{\mathrm{d}}$ for the non-motile species was set higher to introduce the physiological advantage of diatoms. During most of the following experiments, the surface mixed layer (SML) became nutrient depleted and the relevant area for production was the low-light environment of the thermocline. Photo-acclimation (i.e. the choice of $P_{\mathrm{m}}^{\mathrm{l}}$ ) or photo-inhibition (the choice of $I_{\mathrm{d} / \mathrm{l}}$ ) was therefore only important for the transient surface bloom, but not during the steady state situation when the biomass maximum moved into the thermocline.

Nitrogen is the only nutrient accounted for in the model, and we did not distinguish between organic and inorganic species. Ambient dissolved inorganic nitrogen (DIN), $N\left(\mathrm{mg} \mathrm{m}^{-3}\right)$, is taken up and stored internally by the cells. The obvious major difference between diatoms and dinoflagellates is that the former also require silicate to grow, which was not accounted for in the model. For the competition experiment, we assumed that silicate would not be limiting as it is supplied to the SCM from the BML and only taken up by the diatoms, while the local competition would be for the resource that both species require: DIN. The DIN uptake $U$ follows a Michaelis-Menten type function:

$$
U=U_{\max }\left(1-\frac{Q}{Q_{\max }}\right) \frac{N}{\kappa_{\mathrm{N}}+N}
$$

where $Q$ is the cellular nitrogen-to-carbon ratio which needs to remain above a subsistence quota $Q_{\min }$ and below a maximum storage quota $Q_{\max }$ (e.g. Broekhuizen 1999, Liu et al. 2001). $U_{\max }$ is the carbon-specific maximum uptake rate and $\kappa_{\mathrm{N}}$ the half-saturation constant (or the 'nitrogen affinity') (see Table 1 for parameter values and units).

The cellular increase in carbon, $C$, was calculated from a Droop-type function (Droop 1973):

$$
\frac{\mathrm{d} C}{\mathrm{~d} t}=\left[P_{\mathrm{I}}\left(1-\frac{Q_{\min }}{Q}\right)-r-G-L r\right] C
$$

where $r$ is the respiration rate, $G$ the grazing rate, and $L r$ the loss rate due to starvation (see below). For cells in the thermocline, $P_{\mathrm{I}}$ is essentially identical to $P^{\mathrm{d}}$ as $Y$ in Eq. (6) is close or identical to zero.

The above describes the growth of individual cells within the model. The growth of the population of phytoplankton cells is driven by cell division, cell starvation, and grazing. Following Broekhuizen (1999), the process of cell division was incorporated by doubling the number of phytoplankton cells within a Lagrangian particle when the carbon content per cell within that particle reached a maximum, $\mathrm{C}_{\text {fission }}\left(\mathrm{mg} \mathrm{C} \mathrm{Cell}^{-1}\right)$. Conversely, if the cell carbon content drops below a critical value,

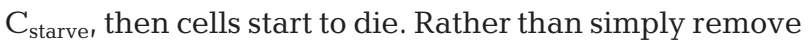
all of the cells in a Lagrangian particle when cell carbon dropped below this critical value, here this mortality was modelled as a discrete loss rate of cells, $\operatorname{Lr}\left(\mathrm{s}^{-1}\right)$, from the population represented by the Lagrangian particle: $L r=$ $0.1 \mathrm{~d}^{-1}$ if $C<\mathrm{C}_{\text {starve }}$ and $L r=0$ otherwise. Grazers were not explicitly modelled, but the grazing impact on the phytoplankton population was incorporated by removing cells from within each Lagrangian particle at a fixed grazing impact rate $G\left(\mathrm{~s}^{-1}\right)$.

Clearly, some Lagrangian particles were 'luckier' than others in that they spent more time in the productive areas of the water column rather than in the light limited BML. To avoid any Lagrangian particle representing a disproportionately large fraction of the total biomass, it was split in two if it carried more than 20 times the appropriate statistical weight. For $N$ particles, a particle was thus split if it carried more than $20 / N$ of the total biomass. Such splitting events were rare but they prevented the fate of the entire population being determined by the fate of a few high-biomass particles. 
As the cell numbers changed within the Lagrangian particles, so the total carbon and nitrogen within the particle changed. While the sinking of detritus and the recycling of organic nitrogen both within the water column and within the sediments were not explicitly modelled, a fraction $\beta$ of the cellular nitrogen released by mortality and grazing was assumed to be recycled immediately by bacterial processes in the water column and returned to the dissolved nitrogen pool (e.g. Tett 1981). This local regeneration of nitrogen was included as a potentially important process when the phytoplankton species had different nutrient affinities. Nitrogen was modelled on a fixed vertical Eulerian grid of evenly-spaced grid elements of thickness $\Delta z=1 \mathrm{~m}$ using the standard diffusion equation. The ambient dissolved nitrogen concentration in the $i$ th depth element, $N_{i}$, thus changed according to:

$$
\begin{gathered}
\frac{\mathrm{d} N_{i}}{\mathrm{~d} t}= \\
\underbrace{\frac{\partial}{\partial z}\left(K \frac{\partial N_{i}}{\partial z}\right)}_{\text {diffusion }}-\underbrace{U C_{i}}_{\text {uptake }}+\underbrace{[r+\beta G]_{i} \hat{N}_{i}}_{\begin{array}{c}
\text { respiration } \\
\text { and grazing }
\end{array}}+\underbrace{\beta L r \hat{N}_{i}^{\text {starve }}}_{\text {starvation }}
\end{gathered}
$$

where $C_{i}$ is the total amount of cellular carbon in the ith depth element. $\hat{N}_{i}$ denotes the total amount of cellular nitrogen in the $i$ th depth element and $\hat{N}_{i}^{\text {starve }}$ is the cellular nitrogen content in those cells that have $C<\mathrm{C}_{\text {starve. }}$ Detritus that was not recycled was assumed to reach the seabed. A fixed concentration of $N_{\text {bed }}=$ $70 \mathrm{mg} \mathrm{N} \mathrm{m}{ }^{-3}$ (Sharples et al. 2001) was held in the model depth element at the seabed as a simple way of including the re-supply of nitrogen to the water column following re-mineralisation processes in the sediments.

Swimming strategies: At the heart of the questions addressed here are the different capacities for vertical migration of diatoms and dinoflagellates (as a representative of a motile species). The model diatoms were treated as neutrally buoyant until their cell nitrogen quota dropped below a factor $f_{\text {diat }}=0.75$ of the maximum nutrient quota $Q_{\text {max }}$. The particle was then given a fixed sinking velocity $w_{\text {diat }}$ until sufficient nitrogen had been taken up to raise the cell quota again above $f_{\text {diat }} Q_{\text {max }}$. This models the widely recognised diatom 'strategy' of sinking to find new supplies of nutrients and relying on turbulence to re-introduce the cells to the photic zone (e.g. Smayda 1997). Dinoflagellates are often observed to employ a vertical migration strategy that is driven by the diurnal variation of light, but that is over-ridden by requirements for nutrients (e.g Cullen \& Horrigan 1981, Smayda 1997). A simple strategy based on light and the cell nitrogen quota was used here:

$$
W_{\mathrm{p}}= \begin{cases}-W_{\text {dino }}, & \text { if } Q<f_{1} Q_{\max } \\ +W_{\text {dino }}, & \text { if } Q>f_{2} Q_{\max } \text { and } I(z)>I_{\mathrm{c}} \\ 0 & , \text { if } Q>f_{2} Q_{\max } \text { and } I(z)<I_{\mathrm{c}}\end{cases}
$$

The cellular N:C ratio, $Q$, increases through uptake of $N$ (Eq. 8) and decreases as a result of carbon assimilation (Eq. 9). If $Q$ falls below a certain fraction $f_{1}$ of $Q_{\max }$ the cell starts to feel nutrient limited and swims toward higher nutrient concentrations, i.e. downward. This assumes that a cell is capable of detecting the ambient nutrient concentration and orient itself accordingly.

As the cells encounter higher nutrient concentrations, $Q$ starts to increase and once $Q>f_{2} Q_{\max }$, the cell feels nutrient replete and begins to swim toward higher light intensities (upward) to minimise light limitation. For this light directed swimming, the cells require a light intensity above some perception threshold $I_{\mathrm{C}}$ in order to determine the upward direction. If the cells experience light below this threshold (i.e. they are too deep or it is night), then a nutrient replete motile cell simply becomes neutrally buoyant. For the present experiments, $I_{\mathrm{c}}$ was chosen such that essentially the entire BML would be above $I_{\mathrm{C}}$ during the light period $T_{\mathrm{D}}$ (see Ross \& Sharples 2007 for a detailed analysis of this parameter).

Considering the thousands of different phytoplankton species in the ocean, it was difficult to avoid choosing $f_{1}$ and $f_{2}$ arbitrarily. Ultimately we settled on a choice that worked, on the basis that something in the thermocline would not be there if it did not have the 'right' set of parameters to survive/compete. For instance, if the value we chose for $f_{1}$ was too low, the cells would swim up for a longer period until they eventually entered the surface mixed layer where they would have to battle against the increased turbulence to reenter the thermocline from above. A too high value for $f_{2}$ on the other hand, would force the cell to swim even deeper in the thermocline and greatly increase the rate of erosion into the BML. The parameter ranges for which an SCM was found to develop were approximately $0.6<f_{1}<0.8$ and $0.6<f_{2}<0.9$, and of course $f_{2}>f_{1}$ at all times.

This was obviously not the only conceivable swimming strategy. If the cells pursued a more geotactic strategy, for instance, our results would look substantially different. However, by being geotactic the population would neither be able to form an SCM, nor would such a strategy be very beneficial to facilitating re-access to the thermocline and thus reduce light limitation. The above strategy was chosen because it has been observed in nature (see 'Introduction') and because it works for the given environment. We also tried a nutrient concentration based strategy, in which the cells simply followed a certain nitrogen concentration (e.g. the half-saturation concentration), thereby 
excluding light as a potentially limiting resource to influence the swimming strategy. The results from these experiments are briefly summarised in the Discussion.

\section{RESULTS}

\section{Expt 1: the diatom only}

Expt 1 contained only the diatom species and was initialised with a uniform nitrogen concentration of $70 \mathrm{mg} \mathrm{N} \mathrm{m}{ }^{-3}$. The results (Fig. 4a) show the develop- ment of a surface bloom, peaking on about Day 8 with the cellular carbon concentration in the SML reaching $0.8 \mathrm{~g} \mathrm{C} \mathrm{m}^{-3}$.

Analogous to the spring bloom, this growth resulted in a nitrate-deplete surface layer separated from a nitrate-replete bottom layer by a nitracline in the base of the thermocline (cf. observations in Fig. 2). The depletion of nitrate in the SML occurred because only $\beta=50 \%$ of the nitrogen released due to grazing and mortality was recycled locally (cf. Eq. 10) while the remaining $50 \%$ was assumed to sink as detritus to the sea bed where it re-entered the water column through
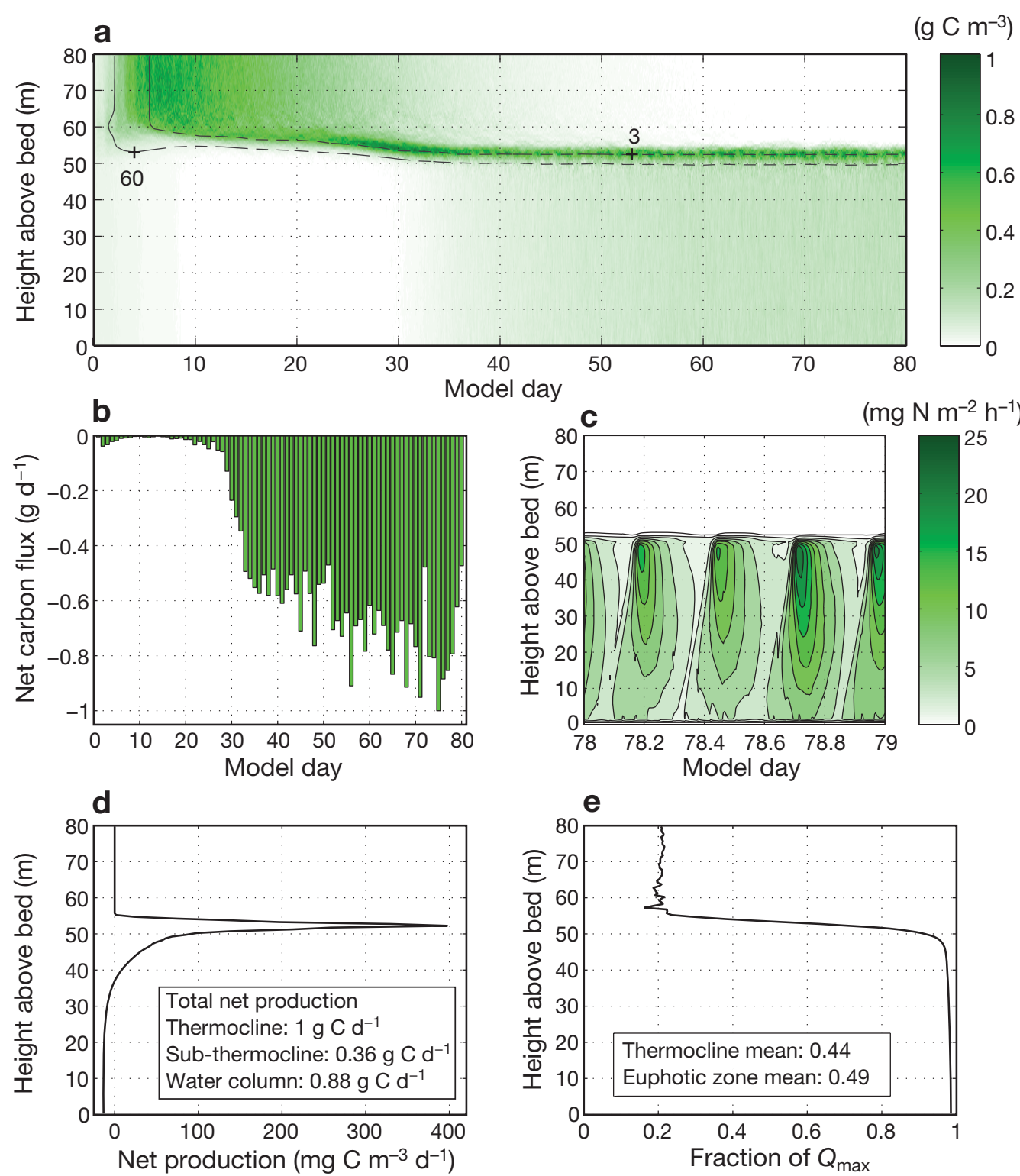

Fig. 4. Expt 1, model with diatom only. (a) Time series of the vertical distribution of cellular carbon and dissolved nitrogen concentration (contours are isolines of DIN $\left[\mathrm{mg} \mathrm{N} \mathrm{m}^{-3}\right]$ ). Nitrogen concentration in the surface mixed layer (SML) $<0.05 \mathrm{mg} \mathrm{N} \mathrm{m}^{-3}$. (b) $\mathrm{Net}$ daily flux of cellular carbon downward from the thermocline into the bottom mixed layer (BML). (c) Upward flux of dissolved nitrogen on model Day 78. (d) Integrated net production (includes respiration, but excludes grazing and starvation losses) on model

Day 79 as a function of depth. (e) Daily mean cellular N:C ratio on model Day 79 as a fraction of $Q_{\max }=0.28 \mathrm{mg} \mathrm{N}\left(\mathrm{mg} \mathrm{C}^{-1}\right)$ 
$N_{\text {bed }}$ (cf. Table 1). As a result, the biomass in the SML declined and by the end of the experiment was only about $1.5 \mathrm{mg} \mathrm{C} \mathrm{m}^{-3}$. The SCM gradually moved deeper, approximately following the $3 \mathrm{mg} \mathrm{N} \mathrm{m}^{-3}$ nitrogen isoline. This downward movement stopped around Day 50 when the daily average carbon in the SCM also reached a stationary concentration. Over the course of a day, the SCM still showed significant variations between 0.7 and $1.0 \mathrm{~g} \mathrm{C} \mathrm{m}^{-3}$ due to the varying solar irradiance and tidal mixing (see below). Significant biomass was also seen in the bottom tidally-mixed layer, where the carbon concentration reached about $0.1 \mathrm{~g} \mathrm{C}$ $\mathrm{m}^{-3}$ on Day 80 . This bottom layer biomass was supplied from the SCM, by both the direct sinking of nutrientdeplete cells and the action of tidally-generated turbulence at the base of the SCM entraining cells into the BML. Fig. 4b shows the daily net flux of carbon from the thermocline into the BML. A particle was counted in the upward flux if it reached $z=51 \mathrm{~m}$ or higher (just within the low turbulence area and out of reach of the tidal turbulence, cf. Fig. 3c) and if it came from below $z=49 \mathrm{~m}$. Conversely, a particle was counted in the downward flux if it was mixed below $49 \mathrm{~m}$ and came from above $51 \mathrm{~m}$. This $2 \mathrm{~m}$ separation in the flux measurement was intended to filter out the short term (random) fluxes and thus only count those particles in the upward/downward flux that spent a significant amount of time in the BML/thermocline. The values obtained in this manner are a slight underestimation of the real fluxes as we neglected export of new production from between 49 and $51 \mathrm{~m}$.

Particles from the BML that contributed to the upward flux were generally low in carbon as they had experienced a period of light limitation, while the particles from the SCM which contributed to the downward flux were high in carbon as they had spent time in the only part of the water column where both light and nutrients are available in sufficient quantities to afford net growth. As a result, there was a net downward export of cellular carbon. During the first $30 \mathrm{~d}$ of the experiment, and especially once the surface bloom started to subside (between Days 10 and 30), the vertical fluxes were small and almost equal in the upward and downward directions. As the SCM started to form and gradually move deeper, the fluxes also increased. After Day 50 when the biomass in the SCM had stabilised, the net downward flux of carbon reached values of about $0.75 \mathrm{~g} \mathrm{C} \mathrm{d}^{-1}$ on average, representing about $27 \%$ of the total thermocline biomass. Since the latter remained stable through this period, the $0.75 \mathrm{~g} \mathrm{C}$ must have come from new production in the SCM. As mentioned previously, the design of the flux measurement led to a slight underestimate of the true values; Fig. 4d shows that the net carbon production in the thermocline averaged $1.0 \mathrm{~g} \mathrm{C} \mathrm{d}^{-1}$. A considerable amount of production also occurred in the sub-thermocline area from $z=40$ to $50 \mathrm{~m}$. The euphotic zone extended to about $z=38 \mathrm{~m}$.

The diffusive flux of DIN from the BML into the thermocline showed a strong tidal signature and reached maximum values of over $20 \mathrm{mg} \mathrm{N} \mathrm{m}^{-2} \mathrm{~h}^{-1}$ during periods when the turbulent intensity at the base of the thermocline reached its maximum (Fig. 4c). There was also a marked diurnal signal with generally higher fluxes during the second half of the day due to the higher growth in the SCM during the light period and the subsequent sharpening of the nitracline. The daily average maximum flux was about $7.8 \mathrm{mg} \mathrm{N} \mathrm{m}^{-2} \mathrm{~h}^{-1}$, occurring at an elevation of $z=35 \mathrm{~m}$ due to the significant sub-thermocline production. At the base of the thermocline, the daily mean was $6 \mathrm{mg} \mathrm{N} \mathrm{m} \mathrm{N}^{-2} \mathrm{~h}^{-1}$, while closer to the seabed it was only $4.8 \mathrm{mg} \mathrm{N} \mathrm{m}^{-2} \mathrm{~d}^{-1}$. This suggests that about $20 \%$ of the flux that reached into the thermocline was recycled nitrogen (e.g. ammonium). In the subthermocline growth region, the influx of recycled nitrogen reached almost $40 \%$. Within the thermocline, the upward flux of DIN quickly dropped to negligible values, mainly because of the reduced turbulence towards the thermocline interior but also due to the consumption by phytoplankton in the SCM.

By multiplying the curves from Fig. $4 d$ \& e with each other and with $Q_{\max }$, we obtained an estimate for the nitrogen requirements to support the net growth. However, instead of using the net growth curve from Fig. $4 \mathrm{~d}$ to obtain the gross nitrogen requirement, we used gross production (i.e. net production plus respiration). In the thermocline this was $225 \mathrm{mg} \mathrm{N} \mathrm{m}^{-2} \mathrm{~d}^{-1}$. Given the daily injection of nitrogen at the base of the thermocline of $6 \mathrm{mg} \mathrm{N} \mathrm{m}^{-2} \mathrm{~h}^{-1}$ or $144 \mathrm{mg} \mathrm{N} \mathrm{d}^{-1}$ (see previous paragraph), we assumed that the remaining requirement of $81 \mathrm{mg} \mathrm{N}$ would be met by recycled nitrogen in the thermocline. This yielded a thermocline $f$-ratio of 0.64 , higher than estimates for most parts of the ocean, although values as high as 0.8 have been observed during transitional upwelling events (Lalli \& Parsons 2002). In the sub-thermocline growth region, the $f$-ratio was about 0.32 .

In a run of the model where the diatoms were kept neutrally buoyant at all times (not shown), the population was overall less successful, having on average $50 \%$ less biomass in the SCM. Although the SCM was located about $2 \mathrm{~m}$ higher than in Fig. 4, at the stability maximum in the thermocline interior and thus at slightly higher light intensities, the greater distance from the base of the thermocline (and the tidal mixing) meant that the supply of nitrogen from the BML to the SCM was less effective, resulting in the reduced growth. Due to the slightly higher position, the downward export of carbon was also reduced to about $25 \%$ of the daily mean SCM carbon concentration, which 
suggested that a significant proportion of the bottom layer biomass was supplied by the sinking rather than tidal turbulence.

\section{Expt 2: two species, no motility}

Expt 1 demonstrated that, in the absence of competition, the model diatom develops a significant SCM in the base of the thermocline. The same result was also obtained for a neutrally buoyant dinoflagellate (not shown). Expt 2 demonstrated that if both species compete, the physiologically-disadvantaged dinoflagellate cannot co-exist with the diatom in the SCM if it is neutrally-buoyant (Fig. 5).

Expt 2 was initialised with a nitrate concentration in the SML already reduced to $5 \mathrm{mg} \mathrm{N} \mathrm{m}^{-3}$ in order to reach the depletion situation more quickly and save computing time. The surface bloom was therefore shorter lived compared to Expt 1.

Aided by immigration of cells from below, the dinoflagellates took part in the initial surface bloom, reaching carbon concentrations of $85 \mathrm{mg} \mathrm{C} \mathrm{m}^{-3}$ (compared to the diatom bloom of $130 \mathrm{mg} \mathrm{C} \mathrm{m}^{-3}$ ). As the experiment progressed, however, and the surface became nutrient deplete, their biomass decreased rapidly. By the end of the experiment they constituted only a negligible fraction of the total biomass in the water column (cf. Fig. 5c). The discrepancy in bloom biomass reached by the 2 species was consistent with the difference in growth rate (Table 1). The carbon and nitrogen fluxes and also the values for new production were similar to those from Expt 1 and are therefore not shown.
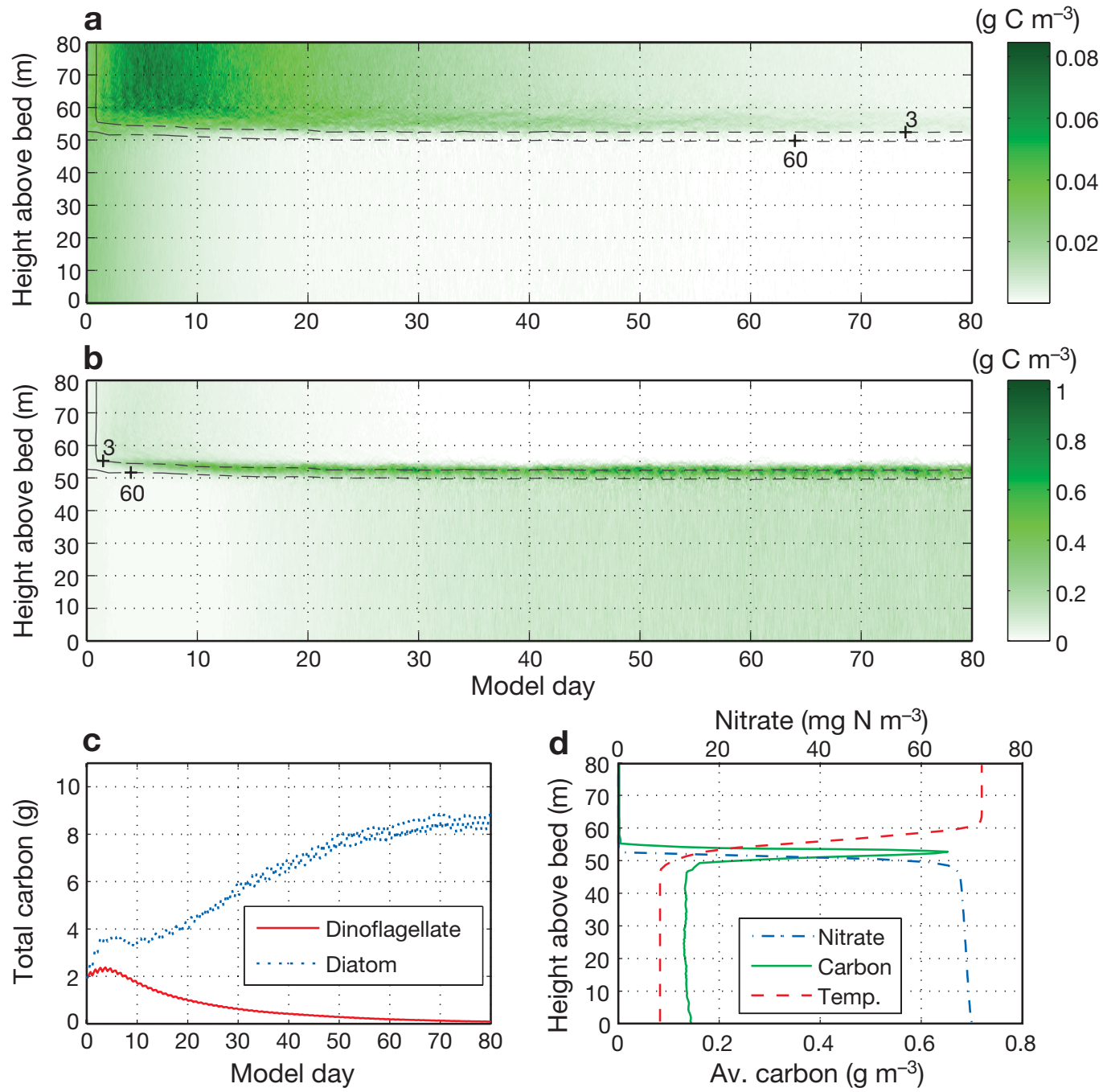

Fig. 5. Expt 2. (a) Time series of the vertical distribution of dinoflagellate carbon. Contours are isolines of DIN [ $\left.\mathrm{mg} \mathrm{N} \mathrm{m}^{-3}\right]$. (b) as in (a) but for diatoms (note different colour scale). (c) Total depth integrated cellular carbon with time. (d) Vertical profiles of (combined) average $\mathrm{C}$ and $\mathrm{N}$ concentration on Day 79. Temp. profile for reference only (without scale, cf. Fig. 3a) 


\section{Expt 3: two species, one motile}

While Expt 2 clearly showed how the neutrallybuoyant dinoflagellate was out-competed by the diatom, Expt 3 showed that an ability to swim at 0.1 $\mathrm{mm} \mathrm{s}^{-1}$ in response to resource needs produces the opposite result: in this case the motile dinoflagellate out-competed the diatom (Fig. 6).
To reach the limiting situation more quickly, this experiment was also initialised with a DIN concentration in the SML already reduced to $5.0 \mathrm{mg} \mathrm{N} \mathrm{m}^{-3}$. The short diatom surface bloom started to decline from about Day 5 onwards and most of the diatom biomass was then located within the SCM, but the population gradually declined. By the end of the experiment, diatoms only made up a negligible fraction of the total bio-
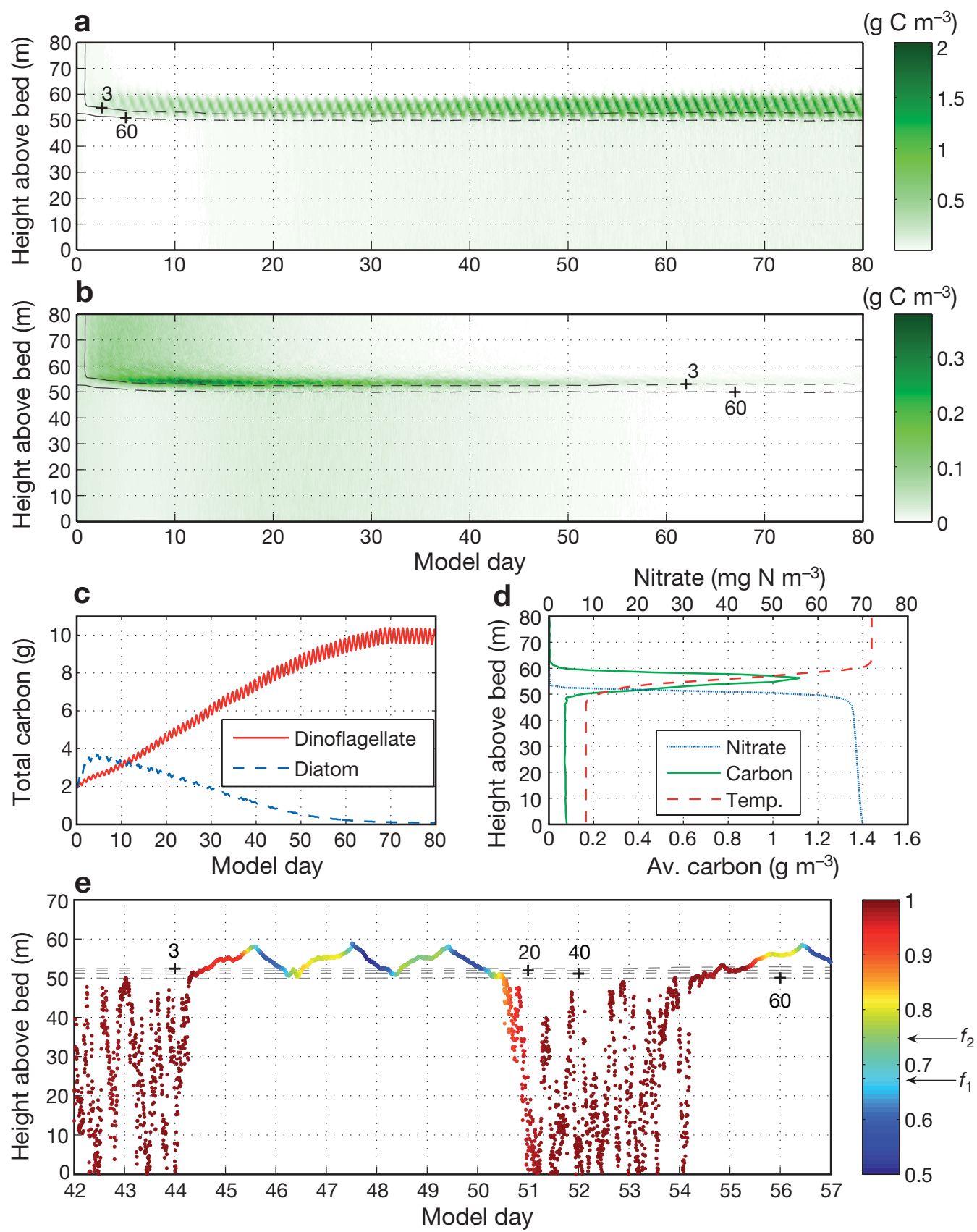

Fig. 6. Expt 3. (a)-(d) as in Fig. 5, but dinoflagellates are motile with $w_{\mathrm{p}}=0.1 \mathrm{~mm} \mathrm{~s}^{-1}$. (e) 2 wk portion of a representative Lagrangian particle track (showing the lower $70 \mathrm{~m}$ of the water column) to illustrate the swimming strategy. Dots $=$ particle location every 5 min and colour coding shows cell nutrient quota as a fraction of $Q_{\max } . f_{1}$ and $f_{2}$ are swimming strategy turnaround points (cf. Eq. 11). Dashes are DIN isolines with labels in $\mathrm{mg} \mathrm{N} \mathrm{m}^{-3}$ 
mass (Fig. 6c). The dinoflagellate population, on the other hand, showed a slow but steady increase, levelling off towards the end of the experiment. A steady state was reached from about Day 70.

The vertical distribution of cells within the thermocline exhibited a marked diurnal oscillation (amplitude approx. 8 to $9 \mathrm{~m}$ ), a result of the resource-based swimming strategy: the cells photosynthesised during the light period, which led to a decrease in the nutrient quota $Q$. Towards the end of the light period, nutrient limitation began to have an effect and the cells swam downward. The location of the (dinoflagellate) SCM thus oscillated between about 50 and $58 \mathrm{~m}$. This synchronisation to the light cycle produced the coherent 'swath'-like pattern in Fig. 6a. With a given swimming velocity of $0.1 \mathrm{~mm} \mathrm{~s}^{-1}$, the cells were not usually able to replenish their nutrient quota until about midday of the following day. As a result, their trajectories show a bidiurnal rather than a diurnal oscillation (cf. Fig. 6e). The daily downward swaths in Fig. 6 were thus produced by 2 different groups of cells. A similarly coherent upward swath is not seen because the higher turbulence at the base of the thermocline disrupted this collective synchronisation.
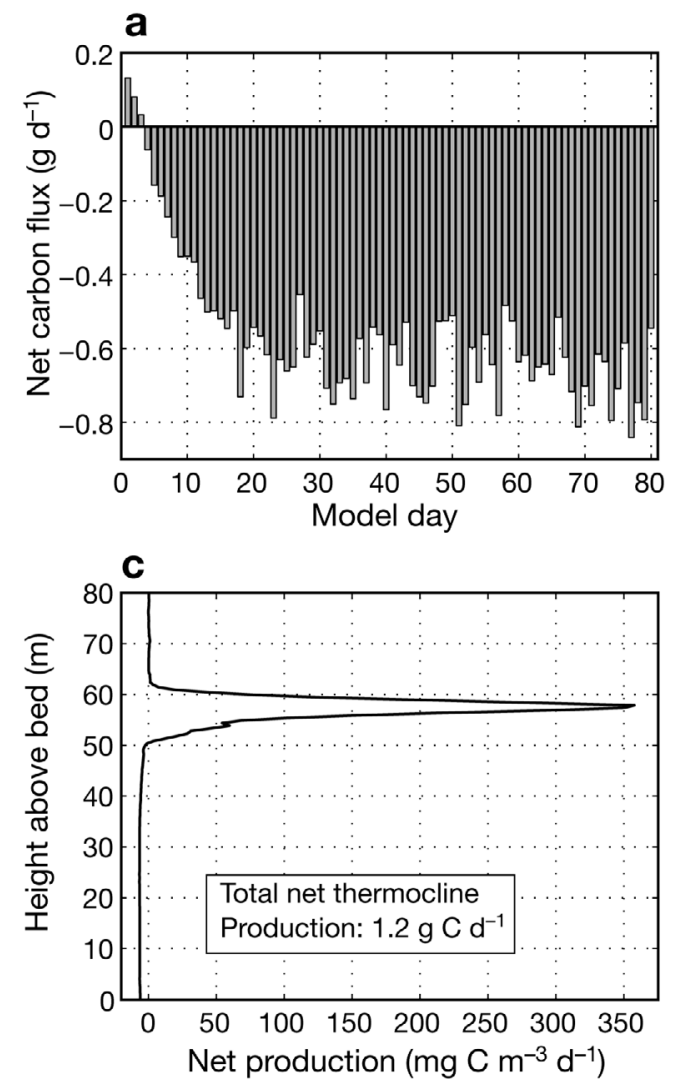

If we compare Fig. $6 \mathrm{~d}$ with Fig. 5 d, we notice that the biomass in the BML is lower in Expt 3 because the values chosen for $f_{1}$ and $f_{2}$ caused the centre of mass of the SCM to lie slightly higher in the thermocline. Thus, fewer cells were eroded into the BML by the tidal mixing, which was also reflected in the relatively low carbon flux into the BML (Fig. 7a). Although the absolute flux was similar to Expts 1 and 2, in relative terms, only $12 \%$ of the SCM biomass was exported into the SCM, compared to about $27 \%$ in Expts 1 and 2. Initially, the net flux was in the upward direction due to dinoflagellates migrating from the BML into the thermocline. This transient effect was caused by the initially uniform particle distribution. The direction of the net flux later reversed and a net export of cellular carbon from the thermocline occurred, with values from 0.6 to $0.8 \mathrm{~g} \mathrm{C} \mathrm{d}^{-1}$.

Although the position of the SCM was relatively high in the thermocline due to the chosen values for $f_{1}$ and $f_{2}$, erosion of cells did occur (cf. Fig. 6e). The dinoflagellates' motility, however, gave them a valuable advantage over the diatoms, facilitating higher reaccess rates to the thermocline (Ross \& Sharples 2007). Re-access can only occur when the tidal turbulence
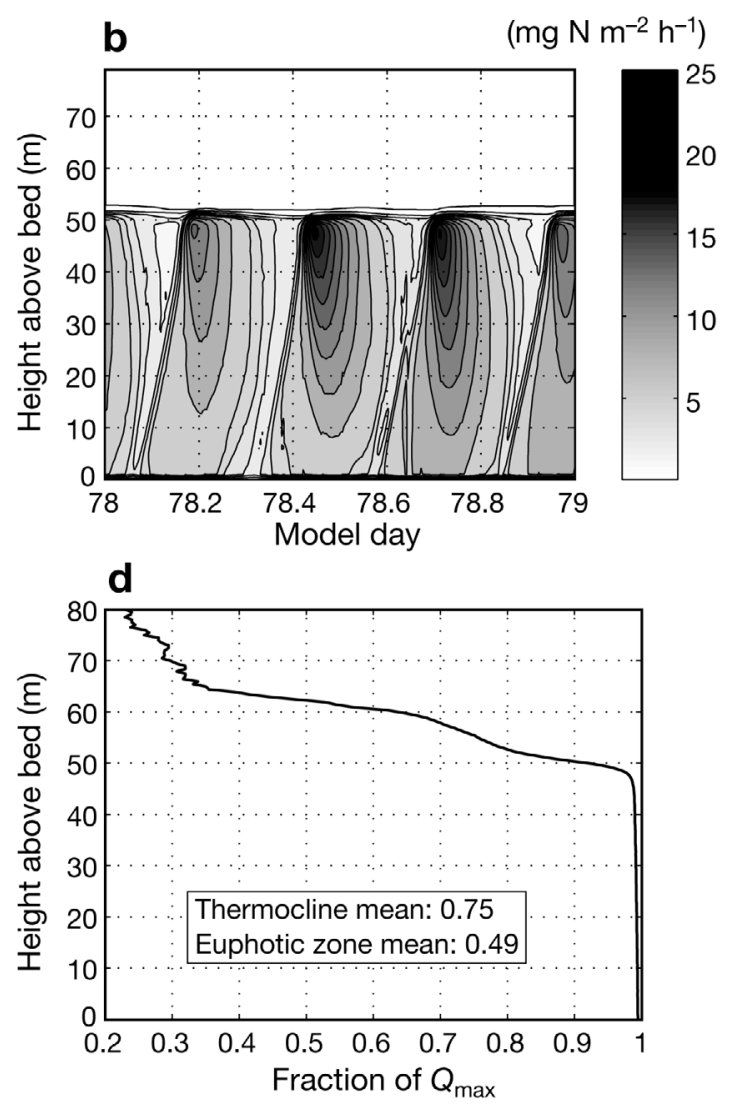

Fig. 7. Expt 3. (a) Total net carbon fluxes. Negative numbers represent a net downward flux, positive numbers upward. (b) Vertical nitrate flux on model Day $79(24 \mathrm{~h})$. (c) Total daily production on model Day 79 as a function of depth. (d) Daily mean cellular N:C ratio on model Day 79 as a fraction of $Q_{\max }=0.28 \mathrm{mg} \mathrm{N}\left(\mathrm{mg} \mathrm{C}^{-1}\right)$ 
brings a cell from the BML within swimming distance of the lower mixing regime of the thermocline interior while the cell has a light cue which causes it to swim upward to higher light intensities (and thus away from the tidal mixing). This occurred on Days 44.3 and 54.6 in Fig. 6e. If a cell was suspended at the base of the thermocline while the light cue was absent, the tidal mixing drew the cell back down into the BML and reaccess usually did not occur (Day 43.0 in Fig. 6e). The missing light cue also disrupted the upward migration in the thermocline (Days 45.0, 47.0, and 49.0 in Fig. 6e).

As in Fig. 4c, the upward flux of $N$ into the thermocline was dominated by the tidal mixing in the BML (Fig. 7b). Due to the vertical migration of the cells within the thermocline, the superimposed diurnal signal was slightly more pronounced, however. The upward flux of $N$ associated with the mixing pulse on Day 78.7, for instance, was twice as high as the flux due to the mixing pulse in the early morning of the same day, although both pulses had the same turbulence intensity. The daily mean maximum flux was about $8.3 \mathrm{mg}$ $\mathrm{N} \mathrm{m}^{-2} \mathrm{~h}^{-1}$ and occurred at the base of the thermocline; however, at the bottom of the BML it was only $5.7 \mathrm{mg}$ $\mathrm{N} \mathrm{m}^{-2} \mathrm{~h}^{-1}$, suggesting that about $30 \%$ of the flux into the thermocline was recycled $N$, more than in Expt 1 due to the non-existent sub-thermocline production (cf. Fig. 7c).

The daily net production (including respiration but excluding losses from grazing and starvation) in the thermocline region averaged $1.2 \mathrm{~g} \mathrm{C}$ (Fig. 7c), roughly the same as the combined thermocline and sub-thermocline production reached by the diatoms in Expt 1 (cf. Fig. 4d). In all our experiments, the tidal currents were representative of a spring tide, which was intended to make it more challenging for the motile species to use motility as a competitive advantage. This high sub-thermocline mixing resulted in high DIN fluxes from the BML into the thermocline, which, together with a constantly high surface irradiance, led to these high growth rates, which are comparable to but still slightly higher than estimates for the North Sea (Richardson et al. 2000, Weston et al. 2005). In reality, the periodic reduction in turbulent mixing with the spring-neap cycle and variability in surface PAR due to cloud cover will-on average - reduce these values. Figs. 7c \& 4d do demonstrate, however, that under favourable meteorological and tidal conditions, a new production of over $1.0 \mathrm{~g} \mathrm{C} \mathrm{d}^{-1}$ in the subsurface is possible, regardless of whether the dominant species is motile or not.

Using the same method as in Expt 1, we estimated the nitrogen requirements in the thermocline as 380 $\mathrm{mg} \mathrm{N} \mathrm{m} \mathrm{m}^{-2} \mathrm{~d}^{-1}$. Given that the supply was only $200 \mathrm{mg}$ $\mathrm{N} \mathrm{m}^{-2} \mathrm{~d}^{-1}$ (see above), we obtained an $f$-ratio of about 0.5 which is lower compared to our estimate for Expt 1.
The higher regenerated production in Expt 3 was due to the longer residence time of the dominant species in the thermocline. According to Expt 1, one out of 4 diatoms, but only one out of 8 dinoflagellates, would be eroded from the thermocline into the BML every day. Thus more grazing, respiration and starvation occur in the thermocline rather than in the BML. It is interesting that while the mean $\mathrm{N}$ : $\mathrm{C}$ ratio in the thermocline was relatively high, we again obtained a near Redfield ratio (as in Expt 1) by extending the spatial average across the entire euphotic zone (Fig. 7d).

\section{DISCUSSION}

The results described in the previous section illustrate 2 broad outcomes: (1) in the absence of any other competitor species, the model diatoms form a SCM in the base of the thermocline, and (2) the diatom outcompetes a physiologically disadvantaged species (in this case a dinoflagellate with lower maximum growth rate) unless it has some migratory capability that offsets its disadvantages by allowing a directed search for light and nitrogen. The fundamental conclusion, therefore, is that the relatively simple migration strategy used in the model, with a swimming speed at the lower end of the motility spectrum of $0.1 \mathrm{~mm} \mathrm{~s}^{-1}$, provides the model dinoflagellates with sufficient advantage to overcome a prescribed deficit in the growth rate and out-compete the diatom.

This discussion focuses on 2 areas: (1) How do changes in swimming speed and the type and magnitude of physiological disadvantages of dinoflagellates affect the competition? and (2) Which of the other known physiological advantages of diatoms play a role in the competition and to what extent can the capacity to swim compensate these?

Whether or not motility can compensate for a higher diatom growth rate depends both on the magnitude of the swimming capability in relation to the growth rate difference and on the success of the swimming strategy. Considering first the impact of growth rate alone (solid line in Fig. 8a), the intersect with the co-existence line occurs at $P_{\max }^{\text {dino }} / P_{\max }^{\text {diat }} \approx 0.4$. A swimming speed of $0.1 \mathrm{~mm} \mathrm{~s}^{-1}$ thus enables the dinoflagellates to compensate up to a 2.5 times higher diatom growth rate.

If we decrease the swimming velocity, the dinoflagellates compete less successfully (Fig. 8b). The smallest velocity of $0.01 \mathrm{~mm} \mathrm{~s}^{-1}$ is just able to compensate a diatom growth rate that is 1.33 times higher. As the velocity increases, the dinoflagellates do increasingly well compared to the diatoms. From about $0.1 \mathrm{~mm} \mathrm{~s}^{-1}$ onwards, however, the situation becomes more complicated and a further increase in $w$ seems counterproductive. At first sight, this result may seem paradoxical 
a

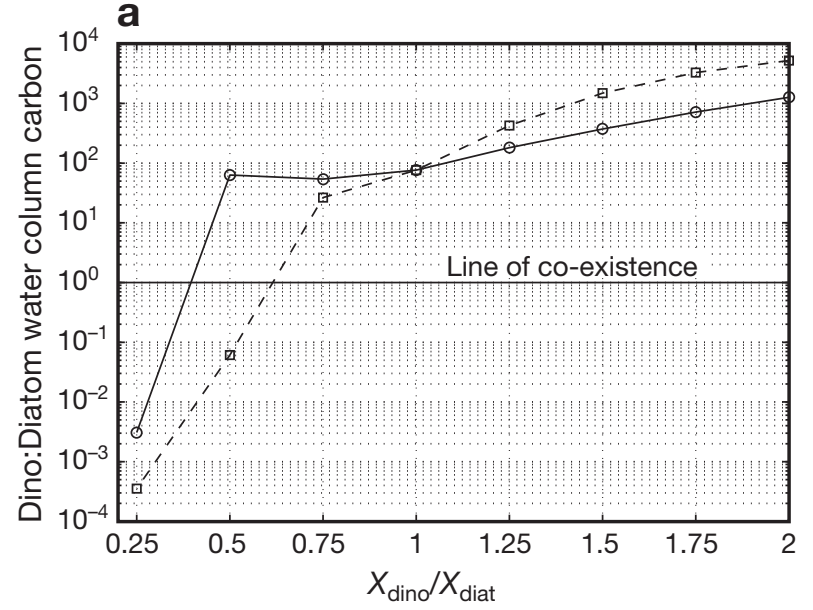

b

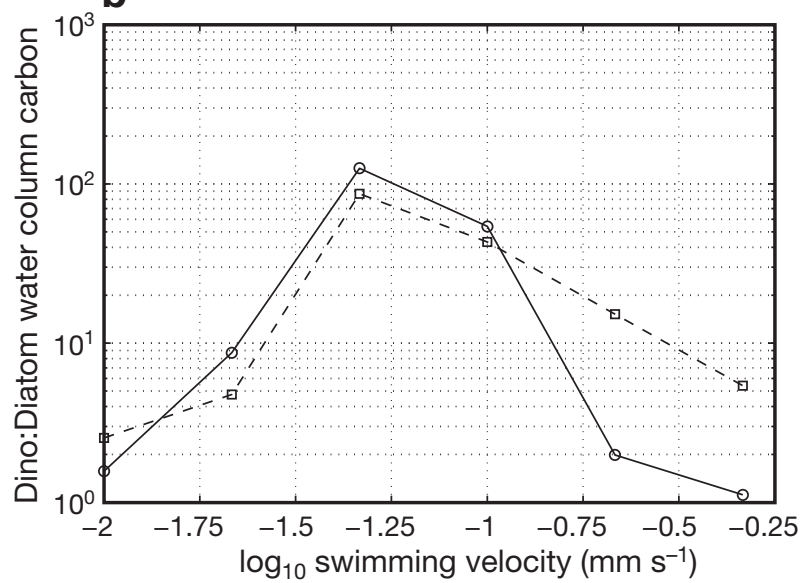

Fig. 8. Dinoflagellate:diatom relative water column C concentration (mean over model Days 70 to 80 ). (a) $W_{\text {dino }}=0.1 \mathrm{~mm} \mathrm{~s}^{-1}$; solid line: different growth rate ratios; dashed line: different growth and nutrient uptake rate ratios. (b) Varying swimming velocity for a fixed dinoflagellate:diatom growth rate ratio $(0.75)$; solid line: light-nutrient-based strategy from Eq. (11); dashed line: nutrient concentration based strategy where cells chase half-saturation concentration $\kappa$ (see Table 1)

as it implies that the dinoflagellates are performing less well in comparison to the diatoms, although the higher swimming velocity should enable them to follow their swimming strategy even better. In order to resolve this apparent paradox we need to consider in more detail what happened over the course of an $80 \mathrm{~d}$ experiment. Fig. 6c shows that the dinoflagellate biomass continually increases until reaching some steady state or the 'carrying capacity' of the water column. This carrying capacity is determined not only by the cells' swimming velocity, but mainly by the water turbidity and, in particular, the amount of self-shading. The increase in biomass continually reduces the amount of light that penetrates to the lower thermocline area, and from a certain point onwards, the increase in biomass comes to a halt simply because the light availability has been reduced to a level at which new growth is compensated by losses from grazing and starvation. Fig. 6e also shows that $Q$ changes most notably in the upper half of the thermocline where the light availability is higher and that the cells require a certain amount of time to accumulate enough carbon to sufficiently reduce $Q$ and reach the upper turnaround point in the swimming strategy which triggers the downward migration (cf. Eq. 11). In Fig. 6e (and for swimming velocities $\leqq 0.1 \mathrm{~mm} \mathrm{~s}^{-1}$ ) this turnaround point is reached while the cells are still within the thermocline. Increasing the swimming velocity beyond $0.1 \mathrm{~mm} \mathrm{~s}^{-1}$ now has 2 effects: (1) the cells traverse the thermocline more rapidly, and thus only reach the turnaround point once they are within the SML, where they then have to battle the higher turbulence in order to re-enter the thermocline and access the influx of nutrients from the BML; and (2) the dinoflagellate bio- mass increases slightly faster and reaches higher concentrations, which in turn produces more self-shading and forces the cells to swim even higher in the water column in order to meet their light requirements.

By abandoning the crucial lower thermocline area and moving into the high turbulence environment of the SML, the dinoflagellates not only become less efficient at pursuing their swimming strategy and meeting their resource requirements, but they also open up a niche for the diatoms which manage to re-establish themselves in the lower thermocline area, thereby increasing the resource pressure on the dinoflagellates even further. The diatoms achieve this recovery simply because the light level is still sufficient for them to achieve positive net growth, and the competition for nutrients has moved higher up in the water column. The decrease in dinoflagellate:diatom carbon at high swimming velocities in Fig. 8b results when a diatom population recovers because a struggling dinoflagellate population stagnates at its carrying capacity and then declines due to an inadequate swimming strategy combined with insufficient light availability in the thermocline.

In an attempt to counteract effect (1) above, we repeated the experiment with a higher value for $f_{1}$, which effectively lowered the turnaround point in the swimming strategy (cf. Eq. 11). As a result (not shown), the cells did indeed stay within the thermocline longer, but as the biomass increased further, effect (2) led again to the dissolution of the SCM as the cells moved into the SML. Thus, adjusting $f_{1}$ only delayed the decline in dinoflagellate:diatom biomass but could not prevent it.

As the swimming strategy from Eq. (11) did not seem to benefit the faster swimmers, we repeated the exper- 
iments using a nutrient concentration based swimming strategy instead, in which the cells hunted for a certain nutrient concentration $N_{0}$. With an appropriate value for $N_{0}$ the dinoflagellates remained within the thermocline, and at high velocities they performed significantly better (see dashed line in Fig. 8b). However, in absolute numbers the nutrient concentration based strategy was less successful, producing a total dinoflagellate biomass $30 \%$ lower than that obtained from the nutrient/light strategy. The extreme concentration of dinoflagellates at a certain nitrogen isoline produced strong vertical oscillations of this isoline due to the diurnal rhythm of photosynthesis. The amplitude of these oscillations became stronger as the swimming velocity (and concentration of cells) increased and as a result the dinoflagellates again spent an increasing amount of time away from the crucial lower thermocline area. The diatoms took advantage of this temporary absence and established a small population there, which again resulted in a noticeable (although less pronounced) decline in dinoflagellate:diatom biomass for the highest swimming velocities.

Although this effect was observed for both swimming strategies, we believe it to be somewhat artificial as it was likely caused by the particular set-up of our experiments. Only the constancy of the physical environment (same semi-diurnal tide and diurnal light cycle for the entire $80 \mathrm{~d}$ of the experiment) and, more importantly, the grazing pressure, made a build-up (and maintenance) of such a high biomass possible. In a real environment, the conditions are much more variable (spring-neap cycle, cloudy days, etc.) and the increasing grazing pressure in response to a high phytoplankton concentration would prevent this selfshading carrying capacity from ever being reached. We therefore believe that under more realistic conditions, an increased swimming capability will always result in an increased competitive advantage. Further work would be needed, however, in order to confirm this hypothesis.

Although high growth rates in diatoms are very common, these are not their only physiological advantage. A significant amount of literature has examined the nutrient affinity $\kappa$, for instance, and although the published values vary by as much as 3 orders of magnitude (compare values of 2 to $400 \mathrm{mg} \mathrm{N} \mathrm{m}^{-3}$ in Smayda [1997] with those of 0.1 to $0.3 \mathrm{mg} \mathrm{N} \mathrm{m}^{-3}$ reported by Anderson \& Roels [1981] or Caperon \& Meyer [1972]), the emerging pattern suggests that diatoms generally have lower $\kappa$ values (although phenomenological reasoning has also produced the opposite assumption [Margalef 1978]). Having a lower $\kappa$ is equivalent to an improved ability to compete for nitrogen at low concentrations, a potentially important competitive advantage in the low nitrogen environment of the thermocline. We tested this assumption by repeating Expt 2 with 2 species identical in all aspects apart from the nutrient affinity, which was reduced in 1 species from 3 to $1 \mathrm{mg} \mathrm{N} \mathrm{m}^{-3}$. In contrast to Expt 2, we did not obtain dominance of a species, but co-existence. For the chosen range of $\kappa$ values and in the particular physical environment of our experiments, $\kappa$ was thus not a significant parameter for species competition. As can be seen in Fig. 6e, most of the uptake occurs at the base of the thermocline, where nitrate concentrations are already considerably higher than $3 \mathrm{mg} \mathrm{N} \mathrm{m}^{-3}$. To turn $\kappa$ into an important competitive parameter, we would have to increase its value by about 1 order of magnitude, but higher $\kappa$ values would reduce the potential growth in the SCM and thus hinder the SCM formation in the first place.

A parameter that has proven far more important to the present study, but that has received considerably less attention in the literature, is the maximum nitrogen uptake rate of the cells $U_{\max }$. Diatoms exhibit relatively high uptake rates when exposed to light and lower rates in darkness, especially for nutrients such as nitrate that require more energy to be assimilated (Eppley et al. 1971, Dortch \& Maske 1982, Litchman et al. 2004). Dinoflagellates show less light dependence, but if averaged over a day-night cycle, diatoms generally have higher uptake rates (Dortch \& Maske 1982). The value for the dinoflagellate uptake rate $U_{\max }$ in Table 1 was chosen in accordance with literature values (e.g. Caperon \& Meyer 1972, Kudela et al. 1997), but based on the reasoning that the maximum nitrogen uptake should be able to support the maximum growth

$$
U_{\max }=Q_{\max } P_{\mathrm{m}}^{\mathrm{d}}
$$

If we apply the same reasoning to the diatoms, we automatically obtain their higher observed maximum uptake rates, and thus an additional competitive advantage. We therefore repeated Expt 3 with a diatom that had both a growth rate and, in accordance with Eq. (12), a maximum nitrogen uptake rate $U_{\max }$ that were 1.6 times higher. As a result, we no longer obtained dinoflagellate dominance, but co-existence.

The dashed curve in Fig. 8a shows the result for different ratios of growth and nitrogen uptake rate. Compared to the solid curve we notice that by adding a second disadvantage, the line becomes steeper. For a ratio of $X_{\text {dino }} / X_{\text {diat }}=0.5$, for instance, we obtain clear diatom dominance, and the swimming velocity of $0.1 \mathrm{~mm} \mathrm{~s}^{-1}$ only compensates for $N$ uptake and a rate of diatom growth that is 1.65 times higher. If just the growth rate is changed (solid curve), the diatoms do not realise their higher growth rate potential due to nutrient limitation, which leads to the prolonged dominance of dinoflagellates.

If, as a third possible disadvantage, we give the dinoflagellates a higher metabolic rate $r$ (cf. Broekhuizen 
1999), as well as lower growth and nutrient uptake rates, then the competitive balance tilts completely in favour of the diatoms and none of the swimming velocities is able to maintain the dinoflagellate population. Qualities other than motility, such as mixotrophy or anti-predation defence, would have to be invoked in order to achieve co-existence or dinoflagellate dominance again. We also performed an experiment which mimicked the experimental set-up of Broekhuizen (1999) where the dinoflagellate growth rate was 2 times lower and its metabolic rate was 2 times higher compared to those of the diatom, but nutrient uptake rate remained the same. Our hypothesis was that although in our experiments the turbulent mixing was much stronger in the BML compared to the almost quiescent conditions in Broekhuizen (1999), our BML was much shallower, which would lead to higher reaccess rates of cells from the BML to the thermocline (aided by the tidal turbulence, cf. Ross \& Sharples 2007), thus providing an additional advantage to the motile species. However, in agreement with Broekhuizen (1999), we found that dinoflagellates could not persist under these conditions. The combination of high metabolic cost and low growth rate was thus detrimental to the dinoflagellates in the low light environment of the thermocline, and other sources of food (mixotrophy) or defense mechanisms against competitors or predators (production of allelochemicals) may be necessary for survival.

Overall, the experiments clearly showed that a sensitive balance among $f_{1}, f_{2}, U_{\max }$ and $w_{\text {dino }}$ is necessary in order for a motile species dominated SCM to develop. If $f_{1}$ is too low or $f_{2}$ too high, for instance, the cells become entrained in the adjacent (and resource limited) boundary layers. If $U_{\max }$ is too low, the cells cannot take up nutrients fast enough, which prolongs downward swimming and leads to higher loss rates to the BML. If $U_{\max }$ is too high, the cells take up nutrients very quickly, and if $f_{1}$ is not adjusted, they need to accumulate more carbon (i.e. swim up for a longer period) in order to reach the turnaround point in the swimming strategy. And finally, if $w_{\text {dino }}$ is too low in relation to $U_{\max }$ the cell cannot adjust its position according to its resource needs and may also be less successful at re-accessing the thermocline from the BML.

Ecosystem models almost always suffer from dependence on a large number of often poorly-constrained parameters. We have found that many parameters have to be just right for the given environmental conditions for motility to provide a competitive advantage. In reality, other adaptations may also be required (e.g. anti-predation defences, mixotrophy, different nutrient dependencies). However, by allowing 2 phytoplankton species to compete within a Lagrangian framework we have been able to demonstrate some key sensitivities, and have shown that an ability to swim in response to resource requirements can compensate the moderate physiological disadvantages of motile cells compared to non-motile species. Motility, even in turbulent environments, is an important factor in understanding the composition and evolution of a phytoplankton community.

Acknowledgements. We thank C. M. Moore and J. J. Waniek for useful discussions which helped to improve this manuscript. We gratefully acknowledge financial support from the European IMPRESS project no. Q5RS-2000-30864 and through NERC research grant NER/A/S/2001/00449. O.N.R. was funded through the MarQUEST initiative as part of the NERC funded QUEST consortium. We are also grateful to the anonymous reviewers for their constructive comments which helped improve the clarity and quality of the present manuscript.

\section{LITERATURE CITED}

Anderson GC (1969) Subsurface chlorophyll maximum in the northeast Pacific Ocean. Limnol Oceanogr 14:386-391

Anderson S, Roels O (1981) Effects of light intensity on nitrate and nitrite uptake and excretion by Chaetoceros curvisetus. Mar Biol 62(1):257-261

Bienfang PK, Szyper JP, Laws E (1983) Sinking rates and pigment responses to light-limitation of a marine diatom: implication to dynamics of chlorophyll maximum layers. Oceanol Acta 6:55-62

Brand L, Guillard R (1981) The effects of continuous light and light intensity on the reproduction rates of 22 species of marine phytoplankton. J Exp Mar Biol Ecol 50:119-132

Broekhuizen N (1999) Simulating motile algae using a mixed Eulerian-Lagrangian approach: Does motility promote dinoflagellate persistence or co-existence with diatoms? J Plankton Res 21(7):1191-1216

Burchard H, Bolding K (2001) Comparative analysis of four second-moment turbulence closure models for the oceanic mixed layer. J Phys Oceanogr 31:1943-1968

Canuto VM, Howard A, Cheng Y, Dubovikov MS (2001) Ocean turbulence. Part I: one-point closure modelmomentum and heat vertical diffusivities. J Phys Oceanogr 31:1413-1426

Caperon J, Meyer J (1972) Nitrogen-limited growth of marine phytoplankton-II. uptake kinetics and their role in nutrient limited growth. Deep-Sea Res 19:619-632

Cullen JJ, Eppley RW (1981) Chlorophyll maximum layers of the Southern Californian Bight and possible mechanisms of their formation and maintenance. Oceanol Acta 4:23-31

Cullen JJ, Horrigan SG (1981) Effects of nitrate on the diurnal vertical migration, carbon to nitrogen ratio, and the photosynthetic capacity of the dinoflagellate Gymnodinium splendens. Mar Biol 62(2-3):81-89

Denman K, Marra J (1986) Modelling the time dependent photoadaptation of phytoplankton to fluctuating light. In: Nihoul J (ed) Marine interfaces ecohydrodynamics. Elsevier, Amsterdam, p 341-359

Dortch Q, Maske H (1982) Dark uptake of nitrate and nitrate reductase activity of a red-tide population off Peru. Mar Ecol Prog Ser 9:299-303

Droop MR (1973) Some thought on nutrient limitation in algae. J Phycol 9:264-273 
Eppley RW, Holmes RW, Strickland JDH (1967) Sinking rates of marine phytoplankton measured with a fluorometer. J Exp Biol Ecol 1:191-208

Eppley RW, Holm-Hansen O, Strickland J (1968) Some observations on the vertical migration of dinoflagellates. J Phycol 4:333-340

Eppley RW, Rogers J, McCarthy J, Sournia A (1971) Light/ dark periodicity in nitrogen assimilation of the marine phytoplankters Skeletonema costatum and Coccolithus huxleyi in N-limited chemostat culture. J Phycol 7:150-154

Field CB, Behrenfeld MJ, Randerson JT, Falkowski P (1998) Primary production of the biosphere: integrating terrestrial and oceanic components. Science 281:237-240

Flynn KJ (2002) Toxin production in migrating dinoflagellates: a modelling study of PSP producing Alexandrium. Harmful Algae 1:147-155

Furnas M (1990) In situ growth rates of marine phytoplankton: approaches to measurement, community and species growth rates. J Plankton Res 12(6):1117-1151

Holligan PM, Harbour DS (1977) The vertical distribution and succession of phytoplankton in the western English Channel in 1975 and 1976. J Mar Biol Assoc UK 57:1075-1093

Horstmann U (1980) Observations on the peculiar diurnal migration of a red tide dinoflagellate in tropical shallow waters. J Phycol 16:481-485

Huisman J, Sommeijer B (2002) Maximal sustainable sinking velocity of phytoplankton. Mar Ecol Prog Ser 244:39-48

Huisman J, Thi NNP, Karl DM, Sommeijer B (2006) Reduced mixing generates oscillations and chaos in the oceanic deep chlorophyll maximum. Nature 439:322-325

Hunter JR, Craig PD, Phillips HE (1993) On the use of random walk models with spatially variable diffusivity. J Comput Phys 106:366-376

Kamykowski D, McCollum AS (1986). The temperature acclimatised swimming speed of selected marine dinoflagellates. J Plankton Res 8(2):275-287

Kudela RM, Cochlan WP, Dugdale RC (1997) Carbon and nitrogen uptake response to light by phytoplankton during an upwelling event. J Plankton Res 19(5):609-630

Lalli CM, Parsons TR (2002) Biological oceanography: an introduction, 2nd edn. Butterworth-Heinemann, Oxford

Large WG, McWilliams JC, Doney SC (1994) Oceanic vertical mixing: a review and model with a nonlocal boundary layer parameterization. Rev Geophys 32(4):363-403

Levandowski M, Kaneta PJ (1987) Behaviour in dinoflagellates. In: Taylor FJR (ed) The biology of dinoflagellates. Blackwell Scientific Publications, Oxford p 360-397

Litchman E, Klausmeier CA, Bossard P (2004) Phytoplankton nutrient competition under dynamic light regimes. Limnol Oceanogr 49:1457-1462

Liu G, Janowitz GS, Kamykowski D (2001) A biophysical model of population dynamics of the autotrophic dinoflagellate Gymnodinium breve. Mar Ecol Prog Ser 210: 101-124

Lizon F, Seuront L, Lagadeuc Y (1998) Photoadaptation and primary production study in tidally mixed coastal waters using a Lagrangian model. Mar Ecol Prog Ser 169:43-54

Lochte K, Ducklow HW, Fasham MJR, Stienen C (1993) Plankton succession and carbon cycling at $47^{\circ} \mathrm{N}, 20^{\circ} \mathrm{W}$ during the JGOFS North Atlantic Bloom Experiment. Deep-Sea Res II 40(1-2):91-114

Lombardi EH, Capon B (1971) Observations on the tidepool ecology and behaviour of Peridinium gregarium. J Phycol 7:188-194

Margalef R (1978) Life-forms of phytoplankton as survival alternatives in an unstable environment. Oceanol Acta 1(4):493-509
Mellor GL, Yamada T (1982) Development of a turbulence closure model for geophysical fluid problems. Rev Geophys Space Phys 20(4):851-875

Nagai T, Yamazaki H, Kamykowski D (2003) A Lagrangian photoresponse model coupled with 2nd-order turbulence closure. Mar Ecol Prog Ser 265:17-30

Pingree RD, Holligan PM, Mardell GT, Harris RP (1982) Vertical distribution of plankton in the Skagerrak in relation to doming of the seasonal thermocline. Cont Shelf Res 1(2):209-219

Richardson K, Visser AW, Bo Pedersen F (2000) Subsurface phytoplankton blooms fuel pelagic production in the North Sea. J Plankton Res 22(9):1663-1671

Ross ON (2006) Particles in motion: how turbulence affects plankton sedimentation from an oceanic mixed layer. Geophys Res Lett 33(10): L10609, doi:10.1029/2006GL 026352

Ross ON, Sharples J (2004) Recipe for 1-d Lagrangian particle tracking models in space-varying diffusivity. Limnol Oceanogr Methods 2:289-302

Ross ON, Sharples J (2007) Swimming for survival: a role of phytoplankton motility in a stratified turbulent environment. J Mar Syst, (in press) doi: 10.1016/j.jmarsys.2006.07.008

Sarthou G, Timmermans KR, Blaina S, Tréguer P (2005) Growth physiology and fate of diatoms in the ocean: a review. J Sea Res 53:25-42

Sharples J (1999) Investigating the seasonal vertical structure of phytoplankton in shelf seas. Marine Models Online 1: $3-38$

Sharples J, Tett P (1994) Modelling the effect of physical variability on the midwater chlorophyll maximum. J Mar Res 52:219-238

Sharples J, Moore CM, Rippeth TR, Holligan PM, Hydes DJ, Fisher NR, Simpson J (2001) Phytoplankton distribution and survival in the thermocline. Limnol Oceanogr 46(3): 486-496

Sharples J, Ross ON, Scott BE, Greenstreet SPR, Fraser H (2006) Inter-annual variability in the timing of stratification and the spring bloom in the northwestern North Sea. Cont Shelf Res 26(6):733-751

Simpson JH, Crawford WR, Rippeth TP, Campbell AR, Cheok JVS (1996) The vertical structure of turbulent dissipation in shelf seas. J Phys Oceanogr 26:1579-1590

Smayda TJ (1997) Harmful algal blooms: their ecophysiology and general relevance to phytoplankton blooms in the sea. Limnol Oceanogr 42(5, Part 2):1137-1153

Tang Y (1995) The allometry of algal growth rates. J Plankton Res 17(6):1325-1335

Tett P (1981) Modelling phytoplankton production at shelfsea fronts. Phil Trans R Soc Lond A 302:605-615

Tilstone GH, Miguez BM, Figueiras FG, Fermin EG (2000) Diatom dynamics in a coastal ecosystem affected by upwelling: coupling between species succession, circulation and biogeochemical processes. Mar Ecol Prog Ser 205: 23-41

Tooby PF, Wick GL, Isaacs JD (1977) The motion of a small sphere in a rotating velocity field: a possible mechanism for suspending particles in turbulence. J Geophys Res 82: 2096-2100

Townsend DW, Thomas M (2002) Springtime nutrient and phytoplankton dynamics on Georges Bank. Mar Ecol Prog Ser 228:57-74

Visser AW (1997) Using random walk models to simulate the vertical distribution of particles in a turbulent water column. Mar Ecol Prog Ser 158:275-281

Weston K, Fernand L, Mills DK, Delahunty R, Brown J (2005) Primary production in the deep chlorophyll maximum of 
the central North Sea. J Plankton Res 27(9):909-922

Woods J, Barkmann J (1994) Simulating plankton ecosystems by the Lagrangian ensemble method. Phil Trans Biol Sci 343:27-31

Woods JD, Onken R (1982) Diurnal variation and primary production in the ocean: preliminary results of a Lagrangian

Editorial responsibility: Otto Kinne (Editor-in-Chief), Oldendorf/Luhe, Germany ensemble model. J Plankton Res 4(3):735-756

Yamazaki H, Mackas DL, Denman KL (2002) Coupling smallscale physical processes with biology. In Robinson A, McCarthy J, Rothschild B (eds) The sea, Vol 12: biologicalphysical interactions in the sea. John Wiley, New York, p 51-112

Submitted: December 8, 2006; Accepted: March 28, 2007 Proofs received from author(s): September 21, 2007 